\title{
Role of PGE-2 and Other Inflammatory Mediators in Skin Aging and Their Inhibition by Topical Natural Anti-Inflammatories
}

\author{
Bryan Fuller 1,2 \\ 1 DermaMedics LLC, Oklahoma City, OK 73139, USA; bfuller@dermamedics.com; Tel.: +1-405-319-8130 \\ 2 Department of Biochemistry and Molecular Biology, University of Oklahoma Health Sciences Center, \\ Oklahoma City, OK 73139, USA
}

Received: 23 November 2018; Accepted: 15 January 2019; Published: 21 January 2019

\begin{abstract}
Human skin aging is due to two types of aging processes, "intrinsic" (chronological) aging and "extrinsic" (external factor mediated) aging. While inflammatory events, triggered mainly by sun exposure, but also by pollutants, smoking and stress, are the principle cause of rapid extrinsic aging, inflammation also plays a key role in intrinsic aging. Inflammatory events in the skin lead to a reduction in collagen gene activity but an increase in activity of the genes for matrix metalloproteinases. Inflammation also alters proliferation rates of cells in all skin layers, causes thinning of the epidermis, a flattening of the dermo-epidermal junction, an increase in irregular pigment production, and, finally, an increased incidence of skin cancer. While a large number of inflammatory mediators, including IL-1, TNF-alpha and PGE-2, are responsible for many of these damaging effects, this review will focus primarily on the role of PGE-2 in aging. Levels of this hormone-like mediator increase quickly when skin is exposed to ultraviolet radiation (UVR), causing changes in genes needed for normal skin structure and function. Further, PGE-2 levels in the skin gradually increase with age, regardless of whether or not the skin is protected from UVR, and this smoldering inflammation causes continuous damage to the dermal matrix. Finally, and perhaps most importantly, PGE-2 is strongly linked to skin cancer. This review will focus on: (1) the role of inflammation, and particularly the role of PGE-2, in accelerating skin aging, and (2) current research on natural compounds that inhibit PGE-2 production and how these can be developed into topical products to retard or even reverse the aging process, and to prevent skin cancer.
\end{abstract}

Keywords: prostaglandin E-2 (PGE-2); ultraviolet radiation; cytokines; inflammation; antioxidants; curcumin; NF-kB; reactive oxygen species (ROS); NSAIDs; COX-2

\section{Introduction: Overview of Intrinsic and Extrinsic Skin Aging}

The visible signs of skin aging are the result of the combined effects of "intrinsic" (chronological) aging, which is due to the passage of time and hereditary genetic influences, and to "extrinsic" aging, which is due to environment factors, predominantly the exposure of skin to UV radiation (photoaging) [1-3]. The clinical signs of intrinsic aging are fine wrinkles, thin and transparent skin, a loss of subcutaneous fat, skin laxity, and dryness [4]. Extrinsic aging encompasses these changes as well as prominent coarse wrinkling, increased and mottled hyperpigmentation, abnormal elastin synthesis (elastosis) [5], significant loss in elasticity, skin roughness, and an increase in both pre-cancerous actinic keratoses lesions and skin cancer [6]. Interestingly, hereditary genetic makeup is thought to account for less than $3 \%$ of the visible and measurable changes in skin structure and function that occur as we age [7]. Much of the chronological skin aging process that is referred to as intrinsic aging is actually due to epigenetic changes in skin cells, and these changes are due, at least in part, 
to inflammation $[2,8]$. As time passes, the skin experiences a low level of chronic inflammation that has often been referred to as "smoldering inflammation" or "inflammaging" [9]. This inflammation causes fibroblasts to switch their gene expression pattern from a matrix building phenotype to a matrix destroying one. The level of collagen synthesis decreases while the production of Matrix Metalloproteinases (MMPs) as well as inflammatory cytokines and chemokines increases $[5,10,11]$. Thus, in regard to intrinsic aging, although there is a genetic component to the chronological aging process, it is difficult to separate the long-term aging events that are due purely to genetic factors from those that are caused by years of low level chronic inflammation resulting from oxidative stress, dietary habits, smoking, alcohol consumption, and health [5,12].

Although intrinsic skin aging is unavoidable, the process is slow unless the skin is exposed to UV radiation (UVR) from the sun. For those who spend a lot of time in the sun, the "extrinsic" skin aging process is dramatically accelerated with noticeable photodamage occurring even at a young age [1,13-15]. This photodamage is the result of both UVA and UVB radiation exposure. UVR can increase the expression of several important matrix metalloproteinases, including MMP-1, MMP-3, and MMP-9 (for a review see [16]). Not only does exposure of skin to UVR increase the levels of enzymes (particularly MMP-3) that degrade collagen, but UVR lowers mRNA levels for both collagen I and III [17]. In addition, recent studies have shown that UVA (but not UVB) exposure increases mRNA and protein levels for the elastase, MMP-12 [18]. The degradation of elastin further contributes to the visible and functional changes in photoaged skin [10]. Finally, mouse studies have shown that UVR decreases the expression of hyaluronic synthases (HAS)-1,-2, and -3 [19]. UVR also increases the expression for hyaluronidases 1 and 2, and it is likely that a combination of these events, coupled with the short half-life of hyaluronic acid in the skin, accounts for the lower levels of hyaluronic acid observed in the epidermis of chronologically and photoaged skin [20-22].

One well known cause of inflammation in both intrinsic and extrinsic aging is the production of Reactive Oxygen Species (ROS) [7,12,23-26]. These include the hydroxyl free radical, superoxide radical, nitric oxide radical, and the peroxyl radical [27]. In addition, other chemicals that can be rapidly converted to free radicals and which trigger inflammation, include hydrogen peroxide, hypochlorous acid, and singlet oxygen. In extrinsic aging, exposure of skin to both UVA and UVB radiation causes a rapid increase in NADPH oxidase leading to an increase in ROS, which then activates signaling pathways in keratinocytes in the epidermis and fibroblasts in the dermis, leading to the activation of inflammatory genes $[23,27,28]$. The pathways activated include those that are downstream from the binding and activation of surface receptors including, but not limited to, the EGF receptor [29,30], PGE-2 receptor [31,32], the TNF-alpha receptor [33], and IL-1 receptor [34,35]. A cartoon that shows a simplified overview of a very complex interplay of signaling pathways involved in the keratinocyte and fibroblast response to UVR and to the ROS produced in response to UVR exposure is shown in Figure 1. Evidence suggests that UVR can activate signaling pathways linked to surface receptors either by causing receptor clustering [36,37], or by producing ROS, which then promote the phosphorylation and activation of downstream signaling pathway intermediates such as ERK1/2 and p38 [30,38-41]. For example, studies have shown that the up-regulation of MMP-1 gene expression in human keratinocytes exposed to UVA involves the activation of the NADH oxidase, Nox1 [23]. This enzyme increases the ROS levels in the cell, and the rise in ROS results in the activation of the MAPK/AP-1 pathway. Phosphorylation and activation of the ERK, JNK, and p38 kinases in this pathway lead to the activation of the AP-1 transcription factor which then increases the activity of the MMP-1 gene [42]. Further evidence that ROS are responsible for the signaling events that lead to MMP-1 gene activation comes from studies showing that if antioxidant gene expression in UVR-treated cells is increased by the Nrf2 transcription factor, ROS levels are reduced and MMP-1 gene expression is prevented [42]. Although UVR activates signaling pathways that typically lead to the activation of many genes, the same signaling pathway can also cause gene repression. As mentioned, one of the most important aging events in both intrinsic and extrinsic skin aging is a loss of collagen, caused by the destruction of existing collagen and the suppression of new collagen synthesis $[10,13,17]$. UVR lowers collagen 
synthesis in fibroblasts through the same AP-1 signaling pathway that causes an up-regulation of MMP genes. In this case, however, the AP-1 transcription factor that is activated by the MAPK/AP-1 signaling pathway, causes suppression of the collagen I and III genes by interfering with the assembly of the transcriptional complex needed for collagen gene expression $[43,44]$.

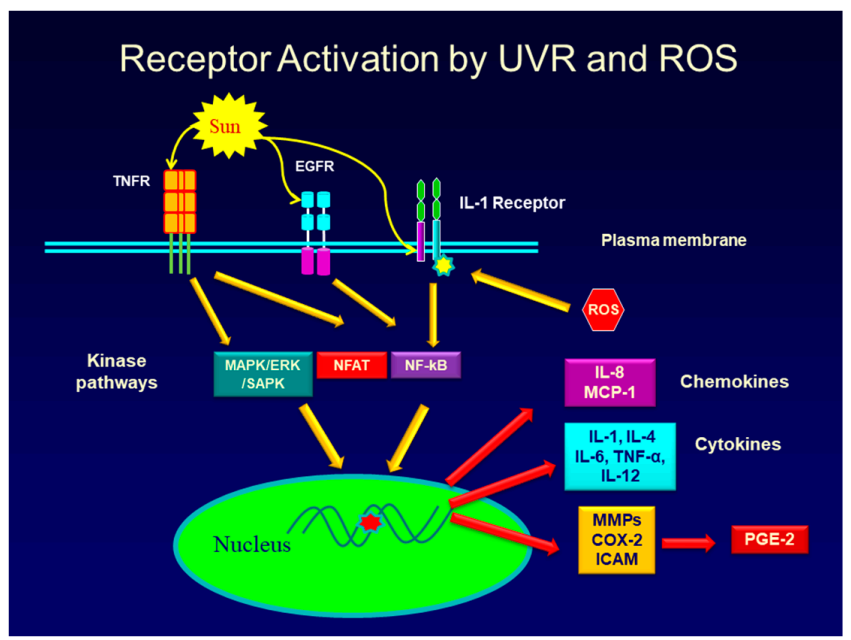

Figure 1. Activation of three signaling pathways in keratinocytes by UVR (ultraviolet radiation) and ROS (reactive oxygen species). UVR can activate surface receptors either directly, or indirectly by increasing the level of ROS, which then leads to receptor activation.

Although not shown in Figure 1, another activator of ROS in skin cells is pollution. Airborne particles less than $10 \mu \mathrm{m}$ microns in diameter (PM10) can cause oxidative damage with ROS production. The ROS activates signaling pathways in keratinocytes that result in the production of TNF-alpha, IL-1, PGE-2, IL-6, IL-8 and MMPs [45].

Even without exposure to sunlight or pollutants, as we age, the level of ROS increases in skin cells, caused in part, by genetically programmed cell death, the breakdown of mitochondria, and by lower antioxidant defense capabilities [7]. This increased level of ROS then activates inflammatory signaling pathways leading to a sustained state of chronic inflammation. Free radicals damage the lipid component of cell membranes, damage enzymes, and damage DNA, which in aged skin has reduced capacity for repair $[2,12,24]$. In addition, the increased damage that occurs in skin as we age, and which includes cellular debris, macromolecule damage, Advanced Glycation Endproducts (AGE) [46], and altered extracellular matrix components, activates a "protective" innate immune response that results in the activation and migration of immune cells into the skin. These cells then produce additional damaging ROS and inflammatory mediators [9,47]. Interestingly, this innate immune response seems to become more active with age. Further, damaged mitochondria in aging skin cells activate the pro-inflammatory Nlrp3 inflammasome, which causes an increase in cytokine production, particularly the production of IL-1 [48]. Finally, as we age the number of senescent cells in the skin increases and these cells produce inflammatory cytokines as well as MMPs [49-51].

As shown in Figure 1, there are three main signaling pathways stimulated by UVR and ROS which are responsible for the activation of many inflammatory genes and genes involved in skin aging. These are the MAP kinase pathway (and related kinases) [52-55], the NF-kB pathway [47,56,57], and the NFAT pathway [58,59]. There is considerable overlap among the pathways in terms of controlling gene activity, so that UVR, ROS, or a particular cytokine, like TNF-alpha, or IL-1, may activate more than one pathway to increase the expression of inflammatory or matrix eroding genes [36,60].

The cytokines, chemokines, and hormones produced by and secreted from keratinocytes and fibroblasts in the skin in response to UVR exposure, further enhance skin aging and inflammation by binding to their specific receptors on adjacent cells in the skin. This binding activates signaling pathways that lead to the further production of inflammatory mediators (a paracrine effect). In 
addition, cytokines such as IL-1, and TNF-alpha, as well as the prostaglandin, PGE-2, can bind to and activate receptors on the same cells they were produced and secreted from (an autocrine effect). Finally, cytokines such as TNF-alpha, and IL-1, as well as PGE-2 can up-regulate the synthesis of their own receptors, thereby further enhancing the inflammatory response [61,62], thus intensifying the damaging effects on the skin. Figure 2 shows some of the complex interaction between inflammatory mediators and target cells in skin.

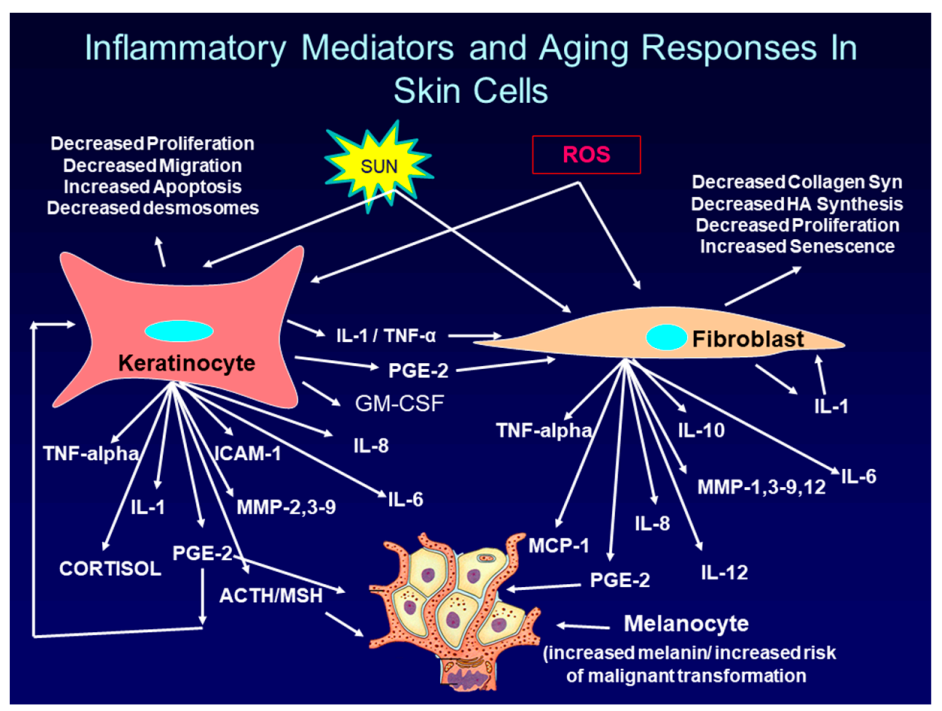

Figure 2. Paracrine and autocrine effects of PGE-2, IL-1 and TNF-alpha in producing and secreting inflammatory mediators from keratinocytes and fibroblasts in response to UVR and ROS. Certain inflammatory mediators (IL-8, TNF-alpha) cause neutrophils and monocytes (not shown) to move from the vasculature to enter the skin where they amplify the inflammatory response. Matrix Metalloproteinases (MMPs) are produced and secreted from keratinocytes, fibroblasts and immune cells migrating into the skin. The hormone, MSH (melanocyte stimulating hormone), and PGE-2 stimulate melanogenesis in melanocytes.

Table 1 lists many of the aging changes in skin structure and function that are caused, at least in part, by inflammation $[7,9,60,63,64]$.

Table 1. A partial list of intrinsic and extrinsic aging events that occur in keratinocytes, fibroblasts, immune cells and melanocytes in response to inflammatory mediators produced in the skin.

\begin{tabular}{c} 
Inflammation Mediated Aging Events in Skin \\
Decreased expression of collagen genes I, III and VII, and particularly collagen-1. \\
Decreased levels of HA and other GAGs. \\
Increased activity of hyaluronidase-1. \\
Increased MMPs causing a loss of collagen and other matrix proteins. \\
Degeneration of the normal elastic fiber network. \\
Increased production of abnormal elastin organization (elastosis). \\
Reduction in lipid synthesis. \\
Loss in energy (ATP) production by mitochondria: increased ROS. \\
Increased influx of immune cells producing inflammatory mediators. \\
Slower keratinocyte and fibroblast cell turnover and cell replacement. \\
Decreased DNA repair of damaged skin cells. \\
Increased senescence of fibroblasts. \\
Increase in Actinic Keratoses and skin cancer. \\
Wncrease in melanogenesis (hyperpigmentation) and solar lentigines \\
Weak epidermal dermal junction. \\
Increased apoptosis of skin cells. \\
\hline
\end{tabular}




\section{The Role of PGE-2 in Skin Aging and Skin Cancer}

\subsection{Regulation of PGE-2 Production in Skin}

PGE-2 plays a key role in the development of skin damage associated with both intrinsic (chronological) and extrinsic aging (primarily photoaging). In regard to chronological aging, studies on full thickness skin samples of sun protected skin taken from over 60 patients ranging in age from 18 to 75, showed that both PGES-1 (PGE Synthase-1) and COX-2 expression progressively increased in dermal fibroblasts with age. This increase in PGES-1 and COX-2 correlated to difference in levels of PGE-2 in the skin. Samples of buttock skin from elderly persons (>80 years old) had PGE-2 levels that were almost twice as high as PGE-2 levels from young (21-30 years old) persons [65]. If fibroblasts derived from young skin were treated with PGE-2, the level of type I procollagen decreased by approximately $60 \%$. Treatment of fibroblast cultures with the COX-2 inhibitor, diclofenac, PGE-2 levels were inhibited by over $90 \%$ and procollagen mRNA and protein expression increased by two-fold [65]. Other studies have compared COX-2 enzyme expression in chronologically aged skin, photoaged skin, and in young skin, and the results show that COX-2 levels are higher in chronologically aged skin and photoaged skin than in young skin [66].

In regard to photoaging, of the two types of UVR that reach the earth's surface to cause skin aging, $95 \%$ is UVA radiation ( $320-380 \mathrm{~nm}$ ) while only 5\% is UVB (290-320 nm). Of the two wavelengths of UVR, UVB penetrates the skin to the upper part of the dermis while UVA can penetrate to the lower reticular region of the dermis. Both UVA and UVB radiation stimulate the production of a variety of inflammatory mediators from keratinocytes and fibroblasts, including PGE-2. Recent studies on biopsies of skin from young and old individuals as well as those with photoaged skin showed that COX-2 protein levels in keratinocytes and fibroblasts were higher in skin samples affected by photoaging than in skin samples from non-photoaged skin of either younger or older patients [67]. As discussed above, UVR stimulates the production of inflammatory mediators in these skin cells through an ROS mediated activation of the NF-kB, MAPK, or NFAT signaling pathways. A few of the key inflammatory mediators produced by keratinocytes and fibroblasts in response to UVR include the cytokines, TNF-alpha and Il-1, the chemokine IL-8, and the paracrine hormone, PGE-2. Many studies over the past 15 years have examined the UVR-mediated cellular events that lead to increased PGE-2 production in keratinocytes, and although there are some conflicting findings on what specific signaling pathways are activated by UVR, there is considerable data to suggest the following sequence of events. The increase in PGE-2 production in keratinocytes by UVR is due, in large part, to the increased expression of the COX-2 gene. Increased transcription of this gene is due to the activation of signaling pathways by ROS. The ROS produced in keratinocytes by UVB radiation promotes the auto-phosphorylation of the EGF receptor and activation of the MAPK pathway (ERK1/2) $[38,63,68]$. Evidence also suggests that ROS can directly activate intracellular kinases involved in the MAPK pathways, for example, ASK-1, without the need for activating the tyrosine kinase domain of a surface receptor [40]. Once activated, the intracellular kinases can phosphorylate and activate transcription factors, including c-fos and Jun, which together form the AP-1 transcription factor [69]. AP-1 binds to a specific site on the COX-2 gene promoter, and in doing so, increases COX-2 gene transcription [70]. Similarly, ROS generated in keratinocytes by UVR can activate the NF-kB pathway, and because there are two binding sites in the COX-2 gene promoter for the NF-kB transcription factor, activation of this pathway also leads to increased COX-2 gene expression, and subsequently increased PGE-2 production [71]. UVR can also activate the COX-2 gene in keratinocytes through the NFAT pathway. ROS produced by UVR causes an increase in intracellular free calcium, which then activates calcineurin, a protein phosphatase. Once activated, calcineurin can dephosphorylate NFAT thereby allowing it to translocate to the nucleus and bind to two NFAT binding sites on the COX-2 gene promotor, thereby increasing gene transcription [72]. Interestingly, in studies where the NF-kB, AP-1, or CRE (a cAMP sensitive site) sites on the COX-2 gene promoter were deleted, although NFAT increased COX-2 gene activity, the response was not as great as that measured when the other promoter sites were 
present. This finding suggests that maximal COX-2 gene activity is dependent on multiple signaling pathways, including the NF-kB, MAPK and NFAT pathways [72]. UVR not only increases PGE-2 levels in keratinocytes, but also increases PGE-2 levels in fibroblasts. In fibroblasts, as in keratinocytes, the MAPK $[17,73,74]$, NF-kB $[17,73]$, and NFAT [75] signaling pathways are involved in regulating the transcriptional activity of the COX-2 gene.

Although UVR increases PGE-2 levels in both keratinocyte and fibroblasts through increased ROS levels, this is not the only mechanism for increasing PGE-2 levels. Inflammatory mediators produced by keratinocytes and fibroblasts in response to UVR, can act in both a paracrine and autocrine manner to further stimulate PGE-2 production. For example, as shown in Figure 2, IL-1, and PGE-2, secreted from keratinocytes after UVR exposure can bind to their receptors on fibroblasts and activate signaling pathways that increase COX-2 gene expression [76-78]. Further, PGE-2 and TNF-alpha can act in an autocrine fashion to up-regulate PGE-2 production from keratinocytes [79-82]. Finally, even the expression of the PGE-2 receptors, EP1, EP2, and EP4 is up-regulated by UVB radiation. These expressed receptors then bind secreted PGE-2 and, in an autocrine fashion, stimulate the production of even more PGE-2 $[31,32,83]$.

In photoaging as well as in chronological aging, keratinocytes and fibroblasts are not the only cells in the skin that produce PGE-2. Within hours of exposure of skin to UVR, neutrophils and monocytes enter the skin and produce a variety of cytokines, chemokines, as well as ROS and PGE-2 [84-87].

While a majority of studies have examined the effect of UVR on the transcriptional regulation of the COX-2 gene, other studies have explored the role UVR plays in up-regulating other steps in the PGE-2 synthesis pathway. Since the PGE-2 synthesis pathway involves three principle steps: (1) the release of arachidonic acid from phospholipids by the action of phospholipase A2, (2) the conversion of arachidonic acid to PGH2 by the action of the cyclooxygenases, COX-1 and COX-2 enzymes, and (3) the conversion of PGH2 to PGE-2 by the action of PGE synthase (PGES), increased production of PGE-2 in skin cells exposed to UVR could be due to increases in any one or more of the enzymes involved in the synthesis pathway. The PGES gene can be induced by UVB radiation [83], by ROS produced by NADPH oxidase [88,89], and by several inflammatory cytokines [86]. Interestingly, the PGES-1 gene is induced in human Alzheimer's disease [90], and in arthritis [91], and evidence suggests that the high levels of PGE-2 in both of these disease states is, at least, partly responsible for the clinical condition. Further, recent studies have shown that the levels of both PGES-1 (PGE synthase 1) and COX-2 are 3.4 and 2.7 fold higher in fibroblasts obtained from the dermis of elderly ( $>80$ years old) than in fibroblasts from younger patients (21-30 years old) [65]. Due to the important role that PGES-1 plays in producing high levels of PGE-2, developing novel drug inhibitors of this enzyme is now an important pharmaceutical research focus $[92,93]$. Finally, both the expression of the phospholipase A2 gene as well as the activity of the enzyme can be increased dramatically by UVB [94,95], by NADH oxidase pathways [96], by MAPK and NF-kB pathways activated by IL-beta, TNF-alpha, and EGF receptors [97], and by cAMP signaling pathways [94,95,98,99].

In conclusion, PGE-2 in both photodamaged and chronologically aged skin is produced by keratinocytes, fibroblasts and by infiltrating immune cells. The cytokines and PGE-2, produced by these cells act through both paracrine and autocrine events, and use multiple signaling pathways to further increase PGE-2 production. Increases in PGE-2 production are the result of UVR, ROS and cytokine induced increases in gene expression and activity of COX-2, PGE synthases, and phospholipase A2.

\subsection{PGE-2 Signals Through Four Receptors}

Regardless of which step in the PGE-2 synthesis pathway is stimulated by an inflammatory event, once produced, PGE-2 contributes to many of the skin aging process shown in Table 1. PGE-2 does this either directly, by altering gene expression in keratinocytes, fibroblasts, immune cells and melanocytes, or indirectly by stimulating the production of other inflammatory mediators in the skin such as IL-1 and TNF-alpha, which then activate signaling pathways that cause skin aging. PGE-2 exerts its effects on target cells by binding to and activating one (or more) of four PGE-2 receptors, 
classified as EP1-EP4 [100]. All four receptors are coupled to G proteins, and the type of G protein subunit determines the intracellular signaling pathway that will respond to PGE-2 [101-103]. The EP1 receptor is linked to the $\mathrm{Gq}$ subunit, which controls the activation of phospholipase $\mathrm{C}$. Activation of this receptor leads to increased protein kinase $C$ activity and increased expression of genes involved in proliferation. The level of the EP1 receptor increases in keratinocytes after exposure of skin to UVR, and several studies have shown that the EP1 receptor is involved in UVR induced skin tumor promotion. Blocking EP1 receptor activity by pharmacological antagonists prevents UVR induced tumor formation in animal models [104]. The EP2 receptor present on keratinocytes, is a low affinity receptor coupled to the Gas subunit. Activation of this receptor leads to increased cAMP levels in target cells and activation of cAMP regulated genes, some of which control keratinocyte proliferation [105]. The EP2 receptor is also linked to tumor promotion, since, in animal models, EP2 knockout mice were resistant to chemically induced skin cancer [106]. The EP3 receptor is the most complex of the PGE-2 receptors because multiple variants of this receptor exist. It is also the most sensitive to PGE-2 of all the receptors, having binding constants in the nanomolar range. This receptor is coupled to the Gi subunit, and when activated, inhibits the production of cAMP, and thus antagonizes the action of the EP1 receptor. As it can be activated by very low levels of PGE-2 in the skin, it can suppress the activity of receptors with less affinity for PGE-2. Unlike EP1 and EP2, the EP3 receptor has been shown to exert anti-proliferative effects on keratinocytes [107]. In vivo animal studies [108] and studies with a PGE-2 sensitive T cell line [109] found that the stimulation of the EP3 receptor by PGE-2 leads to increased expression of MMP-9, which plays a role in collagen destruction in both photoaging and chronological aging. The EP4 receptor, like the EP2 receptor, was originally shown to couple with Gas and stimulate adenylate cyclase, resulting in increased cAMP production. However, more recent studies have shown that the EP4 receptor is also linked to Gai, anrd activation of this subunit leads to the activation of phosphatidylinositol 3-kinase signaling [110]. The EP4 receptor mediates both inflammatory and anti-inflammatory activities. For example, PGE-2 activation of this receptor increases motility of macrophages but at the same time, reduces the production of inflammatory cytokines by these cells [111]. However, EP4 has been shown to be a tumor promoting receptor in skin, and in particular, can increase melanoma proliferation and metastasis [111]. Thus, with the possible exception of the EP3 receptor, all PGE-2 receptors have been found to contribute to the development and progression of skin cancer [100].

Although a detailed discussion of the signaling pathways used by PGE-2 and its receptors to alter the expression of a wide array of genes in skin cells is beyond the scope of this review, Figure 3 shows schematically many of the signaling pathways and gene targets for PGE-2. PGE-2 induced by UVR, binds to and activates EP receptors on keratinocytes, fibroblasts, and immune cells, leading to:

- $\quad$ an increase in MMP production by keratinocytes, fibroblasts and immune cells, which results in the degradation of collagen and elastin [112-114],

- increased production of MCP-1 a chemokine involved in neutrophil and monocyte influx into the skin, resulting in the production of ROS, MMPs, and other inflammatory mediators that damage the dermal matrix [115-117],

- a decrease in collagen I and III and fibronectin mRNA and protein production [65,118],

- an increase in cell senescence [49,119],

- increased scarring during wound healing [120],

- increased malignant transformation of not only skin cells, but cells in other tissues [121-125]. 




Figure 3. Diagram showing the variety of PGE-2 signaling pathways and inflammatory mediators produced in cells that express EP1-EP4 receptors. The EP1 receptor activates a Gq protein that activates phospholipase C producing diacylglycerol (DG) and Inositol triphosphate (IP3). Diacylglycerol activates protein kinase $\mathrm{C}$ (PKC). The EP2, and EP4 receptors are coupled to a Gs protein that activates adenylate cyclase, leading to increase cAMP production. cAMP activates Kinase A, and this kinase can activate other signaling pathways. EP3 (not shown) is coupled to a $G$ protein that prevents an increase in cAMP. EP4 also activates the PI3/AKT pathway levels to increase cAMP levels. In addition to effects of PGE-2 in regulating genes that cause skin aging, evidence shows a role for EP1, EP2, and EP4, but not EP3 in the development of skin cancer.

One of the most obvious changes in photoaged or chronologically aged skin is the loss of dermal matrix proteins, including collagen I, III, elastin, and hyaluronic acid. The degradation of collagen and elastin is the result of increased levels of MMPs in the skin, particularly MMP-1, MMP-3, and MMP-9 [16]. UVR, as well as UVR-induced cytokines, IL-1 and TNF-alpha, and PGE-2, up-regulate MMP gene expression in fibroblasts, keratinocytes [112], and in infiltrating neutrophils [84,126]. Further, as mentioned, UVR-induced PGE-2, produced by and secreted from keratinocytes and fibroblasts, up-regulates the production of IL-1 and TNF-alpha, and both of these cytokines increase the expression of MMP genes in fibroblasts and keratinocytes, leading to further damage to the extracellular matrix (ECM) $[13,127]$. Finally, PGE-2, acting through the EP4 receptor, increases the expression of MMP-9 in monocytes/macrophages that migrate into the skin after UVR exposure [114].

Although PGE-2 up-regulates the expression of MMP genes, it has the opposite effect on collagen gene expression [128]. Studies on human fibroblasts have shown that PGE-2, produced and secreted by these cells, in an autocrine response, binds to the EP4 receptor, and causes a down-regulation of collagen I gene expression, while at the same time stimulating an increase production of both MMP-1 and MMP-3 [129]. Other studies have suggested a role for the EP2 receptor in the PGE-2 mediated reduction in collagen synthesis in fibroblasts. This conclusion is based on the fact that levels of the EP2 receptor are lower in fibroblasts derived from keloid tissue, that produce high levels of collagen, than in 
fibroblasts from normal skin. Further, forskolin treatment of fibroblasts from either skin type, lowered collagen synthesis, indicating that cAMP, the downstream regulator of the EP2 receptor, is involved in the down-regulation [130] Although the signaling pathway used by PGE-2 to down-regulate collagen I gene expression has not been elucidated, studies on lung fibroblasts showed that cAMP, functioning through protein kinase A, phosphorylates and activates CREB (cyclic AMP response element binding protein). This transcription factor then binds the CRE site in the promoter region of the collagen I gene, and through this interaction, inhibits gene transcription [131].

Finally, not only does PGE-2 up-regulate MMP expression and down-regulate collagen gene expression, but it has also been shown to down-regulate the expression of TIMP genes (Tissue Inhibitors of MetalloProteinases) in fibroblasts [132] as well as epithelial cells [133].

In addition to a loss of collagen, elastin and other components of the extracellular matrix, photoaged and chronologically aged skin shows a marked increase in the number of senescent fibroblasts. These cells are still viable, but they will not proliferate, and their gene expression pattern is altered. They have a reduced capacity to make collagen and TIMPs, but an increased capacity to make and secrete MMPs. The role of PGE-2 in promoting cellular senescence and changes in gene expression has been studied in cultured dermal fibroblasts that were "aged" in culture through multiple cell divisions to a senescent phenotype, indicated by the expression of the senescent marker, beta-galactosidase [134]. In senescent fibroblasts, COX-2 and PGE-2 levels were found to be elevated, as was the level of MMP-1 expression. In contrast, the levels of TIMP-1 and procollagen expression were decreased. Treatment of fibroblasts with the COX-2 inhibitor, NS-398, inhibited the senescence-associated increases in COX-2, PGE-2 and MMP-1 as well as the senescence related decrease in TIMP-1 and procollagen [135]. In other studies, treatment of human fibroblasts with inhibitors of COX-2 or PGES-1, or with antagonists of EP receptors prevented senescence as shown by an absence of proliferation arrest and an absence of beta galactosidase positive cells [49].

Another sign of skin aging, and particularly of photoaging, is the occurrence of hyperpigmentation. Excess melanin production in localized areas of the skin, either caused by an increased number of melanocytes in a given area, or caused by increased melanin production by a constant number of melanocytes, leads to various hyperpigmentation conditions that increase with age [136-138]. Although there are a number of UVR-induced hormone-like factors, including MSH, ACTH, and Endothelin-1, that can stimulate melanin production in melanocytes, PGE-2 is one of the most potent stimulators of pigmentation in human melanocytes [139-142]. Thus, the increase in the synthesis of PGE-2 and its secretion from keratinocytes and fibroblasts as a result of sun exposure, plays a significant role in the formation of hyperpigmentation and solar lentiginese ("age spots") [141,143]. Recent studies have shown that PGE is also produced by melanocytes in response to UVR and in an autocrine response, binds PGE-2 receptors on melanocytes and stimulates pigmentation [141]. PGE-2 not only increases melanin production in melanocytes, but it increases dendrite formation and enhances melanosome transfer from melanocytes to keratinocytes [144,145]. Finally, UVR activates the proteinase-activated receptor-2 (PAR-2) on keratinocytes, and this activation results in two events. First, PAR-2 activation allows keratinocytes to internalize melanosomes, and as the keratinocytes move to the skin's surface, they carry the ingested melanosomes with them. Once they reach the surface, the skin becomes visibly pigmented. Secondly, not only does PAR-2 activation increase melanosome transfer, but PAR-2 stimulates PGE-2 production in keratinocytes, thereby further enhancing melanogenesis [146]. While "sun worshipers" consider a "tan" a sign of health, it is, in fact, a sign of inflammation and skin damage, and prolonged stimulation of melanocytes by UV radiation, as is found in tanning beds, invariably leads to irregular hyperpigmentation and more seriously, can lead to transformation of melanocytes into melanoma [147].

\subsection{Effects of PGE-2 on Skin Cancer}

Of all the aging effects that PGE-2 is linked to, its well-recognized role in skin cancer is perhaps the most important event that occurs with increasing age and sun exposure. Further, PGE-2 not only has a 
causative role in skin cancer, but is also linked to many different types of human cancers [148-152]. In fact, a search of PubMed with the key words "COX-2" (or "PGE-2") and "Cancer," identifies well over 1000 research articles that link PGE-2 with either the development or progression of a variety of cancers including basal and squamous cell carcinoma and melanoma [153-156].

As mentioned, of the four EP receptors that PGE-2 binds to, evidence suggests that primarily EP1 [104,122], but also EP2, and EP4, but not EP3, play a role in tumorigenesis (for review see [100]). Much of the evidence for a role of PGE-2 in promoting skin cancer has been obtained from studies on human skin cells and from studies with chemically and UV-light induced mouse skin cancer models. A small sample of the overwhelming evidence that implicates a role for PGE-2 in the development of skin cancer is as follows:

1. Increased COX-2 expression (as detected immunohistochemically) occurs in mouse skin neoplasms that develop after chronic exposure to doses of UVB [157] or to chemically initiated tumor promotion [158].

2. Treatment of mice either orally or topically with COX-2 inhibitors, indomethacin, diclofenac, or with the selective COX-2 inhibitor, celecoxib, during UVB induced carcinogenesis, prevented the development of tumors by $85 \%$. Further, celecoxib caused regression of pre-existing tumors [158-163].

3. Irradiation of hairless mice with a UVA sunlamp, similar to those used in tanning beds, resulted in skin cancers being present in $90 \%$ of the animals. The tumors were assessed to be squamous cell carcinoma and COX-2 levels in these tumors was elevated. The tumor-bearing mice were then divided into two groups and one group was fed a diet containing celecoxib. After 2.5 months, those animals treated with celecoxib had 50\% fewer tumors than the control group $[124,158,160$, $161,163,164]$.

4. In COX-2 deficient or COX-2 knockout transgenic mice, treatment with UVB or chemical carcinogens, resulted in fewer tumors than were formed in normal mice, while the over-expression of the COX-2 gene in transgenic mice enhanced UVB-induced tumor development [165-167].

5. Treatment of mice with a prostaglandin EP1 receptor antagonist, reduced the development of tumors after UVB treatment [104]. In transgenic mice that over-expressed the EP1 receptor, treatment with the chemical carcinogen, DMBA (7,12-dimethyl-benz[a]anthracene), produced a nine fold increase in skin carcinomas compared to wild-type mice [125].

6. COX-2 expression is increased in UVB treated human skin and in human basal cell and squamous cell carcinomas, as well as in actinic keratoses [121,165,168].

7. In melanoma patients, $93 \%$ to $95 \%$ of the tumors expressed COX-2, while no benign nevi were positive for COX-2. Treatment of human melanoma cell cultures with a specific COX-2 inhibitor prevented migration and invasion of melanoma cells suggesting that lowering PGE-2 may reduce metastasis [121,169]. Further, there was a significant correlation between COX-2 expression and disease-specific survival [169].

8. The use of the COX-2 inhibitor, celecoxib, along with a PKC inhibitor, reduced melanoma metastasis in mice injected with melanoma cells [170].

There is so much evidence for the role of COX-2/PGE-2 in causing and promoting cancer cell growth that numerous cancer studies are now focused on the use of COX-2 inhibitors as chemotherapeutic treatments and on the development of new COX-2 inhibitors for use in treating a variety of cancers that are linked to high levels of PGE-2/COX-2. These cancers include esophageal, colon, pancreatic, hepatocellular, lung, prostate, ovarian, breast as well as skin cancers [100,148,149,158,168,171].

When one realizes that over 3 million Americans are diagnosed with skin cancer every year and that one in five Americans will develop some form of skin cancer in their lifetime, it is clear that new approaches are needed to reduce the incidence of this disease. Since it is estimated that over $90 \%$ of skin cancers are associated with exposure to UV radiation $[123,171]$, staying out of the sun is one 
excellent way to reduce the risk of developing skin cancer as we age. Given the large number of studies that now show a causative role for PGE-2 in skin cancer $[149,171]$, it seems likely that suppressing the increase in PGE-2 that is caused both by chronological age and by external factors, primarily sun exposure, should reduce the incidence of pre-cancerous skin lesions (actinic keratoses), basal cell and squamous cell carcinoma, and finally, melanoma.

\subsection{Effects Inhibition of PGE-2 Production by NSAIDs and Natural Compounds}

Due to the diverse deleterious effects of PGE-2 on the structural integrity of the skin, as well as its causative role in skin cancer, research efforts have focused on identifying drugs as well as natural compounds that can block the expression and/or action of PGE-2. A few NSAIDS (non-steroidal anti-inflammatory drugs) that block PGE-2 production and which have been on the market for many years include the common COX-2 inhibitors, aspirin, Ibuprofen, ketoprofen, piroxicam, naproxen, celecoxib, indomethacin and diclofenac. Of these, several have been formulated into topical products to treat, primarily, joint or muscle pain. Topical products include those with ibuprofen, indomethacin, ketoprofen, or diclofenac [159]. Due to the role of PGE-2 in sunburn, it is not surprising that topical COX-2 inhibitors have been shown to be effective in reducing the intensity and duration of a sunburn [159,172]. In addition, a topical formulation containing the COX inhibitor, diclofenac (it is non-selective for COX-1 and COX-2), and sold under the trade name of Solaraze ${ }^{\circledR}$, is now approved by the FDA for the treatment of Actinic Keratoses, an approval which suggests that PGE-2 plays a key role in the development of pre-cancerous, as well as cancerous skin lesions [159].

Although there are many COX inhibitors (either non-selective or selective for COX-2) on the market, there is still considerable interest in identifying safer, natural compounds that can be used topically to effectively block PGE-2 production, as well as block the production and/or action of other inflammatory mediators that cause skin damage, skin cancer and skin aging. Further, because basal levels of PGE-2 increase with age, unless topical products are developed that can suppress this age-related increase, the skin will continue to be damaged as we get older, and the risk of developing skin cancer will continue to increase. Our laboratory has focused on identifying natural compounds that can be formulated topically for use in treating inflammatory skin problems. Our screening program determines which natural compounds are effective in blocking a wide variety of inflammatory cytokines, chemokines, and PGE-2 in human keratinocytes, fibroblasts and immune cells. A summary of some of this previously unpublished screening data is shown in Table 2. As has been reported by others $[173,174]$, curcumin is perhaps the most potent natural compound available for blocking a wide variety of inflammatory mediators, including PGE-2, and for protecting the skin from photoaging $[175,176]$. As shown in Table 2, curcumin is able to completely suppress the UVR or TPA mediated increase in PGE-2, IL-1, and TNF-alpha. While this data is from keratinocyte studies, curcumin is just as effective in blocking inflammatory mediator production in human fibroblasts and in monocytes. Curcumin effectively blocks the IL-1 mediated increase in PGE-2 even at $10 \mu \mathrm{M}$. Similarly, the colorless derivative of curcumin, tetrahydrocurcumin is also effective in blocking the IL-1 induced increase in PGE-2 in fibroblasts (data not shown). As curcumin is an extremely potent natural anti-inflammatory, anti-cancer, and anti-microbial compound, it has been called "Indian Gold" and has been widely studied [173]. There are hundreds of research publications and reviews providing a wealth of information on its anti-inflammatory effects and mechanism of action. In regard to its mechanism of action, curcumin prevents the activation of transcription factors apparently by interfering with the early steps in the signaling pathway, perhaps even by interfering with scaffolding events at the membrane receptor $[174,177,178]$. Through this interference curcumin antagonizes many steps in the inflammatory signaling pathway, including blocking AP-1 mediated transcription events, and blocking the activation of nuclear factors NF-KB, iNOS, and JNK $[179,180]$. 
Table 2. Anti-inflammatory effects of natural phenolic compounds. Human keratinocyte cells were seeded into 12 well culture dishes and allowed to attach overnight. For irradiation experiments cultures irradiated with $50 \mathrm{~mJ}$ of UVB radiation, and fresh medium added that contained either the compound under investigation $(100 \mu \mathrm{M})$ or the solvent for the compound used as vehicle control. After $24 \mathrm{~h}$, medium was removed and assayed by commercial ELISA assay kits for either PGE-2, TNF-alpha, or IL-1. For experiments with TPA cells were treated with TPA (phorbol 12-myristate 13-acetate, 20 $\mathrm{ng} / \mathrm{mL}$ ), or $0.2 \% \mathrm{DMSO}$ as a control After $24 \mathrm{~h}$ medium was removed and assayed by ELISA for PGE-2, TNF-alpha or IL-1.

\begin{tabular}{|c|c|c|c|c|}
\hline & & \multicolumn{3}{|c|}{$\begin{array}{c}\text { \% Inhibition of Inflammatory Mediator Production } \\
\text { in UVR or TPA Treated Keratinocytes }\end{array}$} \\
\hline & Mediator $\rightarrow$ & PGE-2 & TNF-alpha & IL-1 \\
\hline Compound (100 $\mu \mathrm{M})$ & Structure $\downarrow$ & & & \\
\hline Curcumin/Tetrahydrocurc & & 100 & 100 & 100 \\
\hline Quercetin & & 96 & 100 & 88 \\
\hline Luteolin & & 69 & 95 & 32 \\
\hline Myricetin & & 5 & 95 & 90 \\
\hline Dihydroeugenol & & 95 & 65 & 94 \\
\hline Kaempherol & & 100 & 100 & 89 \\
\hline Caffeic Acid & & 31 & 86 & 82 \\
\hline Epigallocatechin Gallate & & 42 & 100 & 83 \\
\hline
\end{tabular}

It is interesting to note, from Table 2, the difference in anti-inflammatory activity between quercetin and myricetin. These compounds are almost identical in structure with the exception of two extra hydroxyl groups in the structure of myricetin. However, with just this structural change, myricetin has no ability to block PGE-2 production in human skin keratinocytes treated with UVR, while quercetin almost completely blocks the stimulation of PGE-2 in keratinocytes. The table also shows that many compounds with the ability to block PGE-2 production, are also effective in blocking the production 
and/or action of two other inflammatory mediators, IL-1 and TNF-alpha, that also damage skin and accelerate the aging process. One likely reason that many of these compounds are effective in blocking the production of more than one inflammatory mediator is that the genes responsive to all three of these cytokines are regulated, at least in part, through an NF-kB regulatory site in the promoter region of the gene. By blocking the activation of NF-kB, these natural compounds may prevent the activation of many genes that require a functional NF-kB transcription factor to bind to their promoter regions [33]. The promoter region of the COX-2 gene has several response elements that can regulate the activity of the gene, as shown in Figure 4. Other genes that also have NF-kB regulatory elements in their promoter region include the IL-1, IL-12, TNF-alpha, PGES, and MCP-1 genes [86,115].

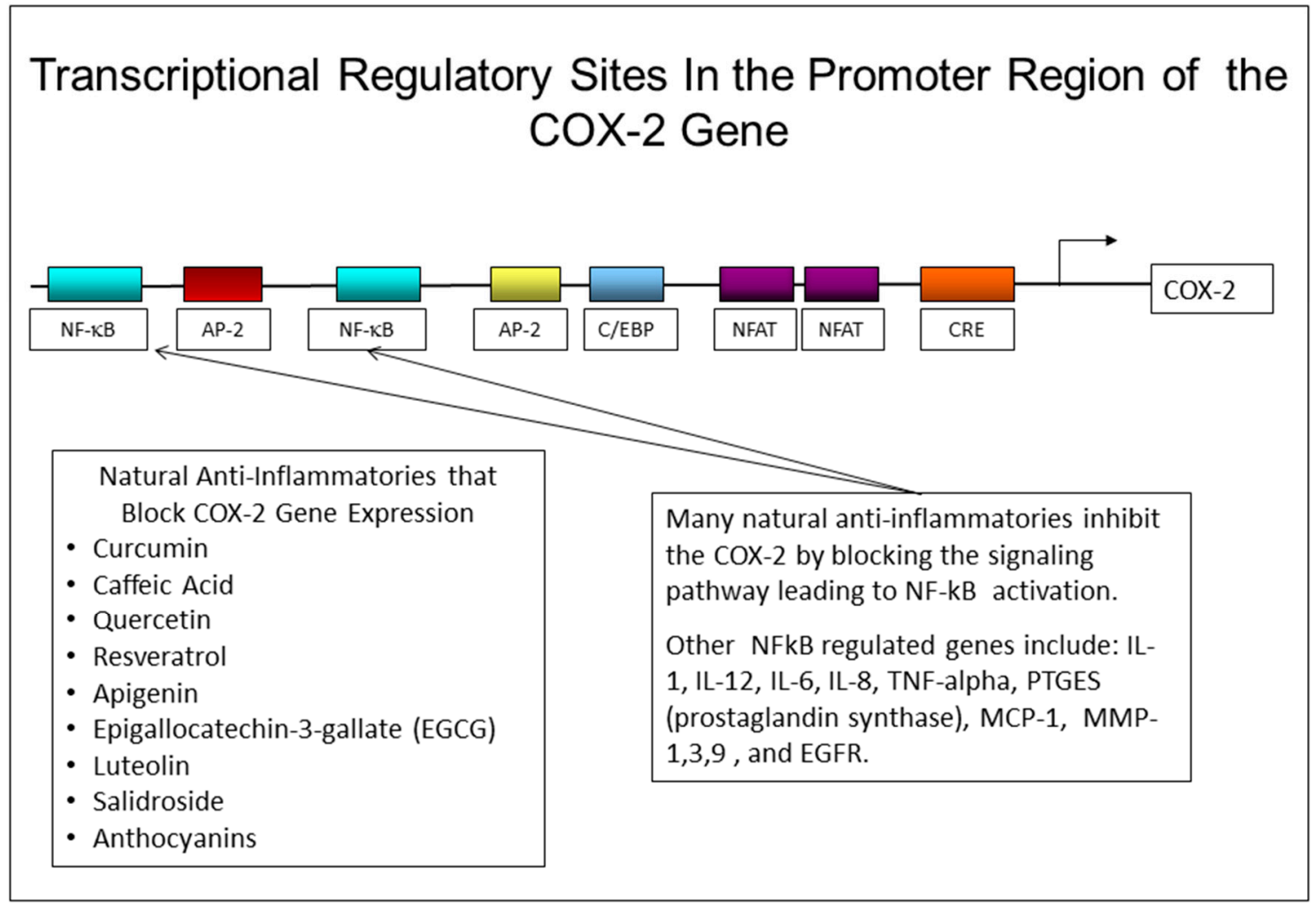

Figure 4. The promoter region of the COX-2 gene showing the binding sites for the transcription factors, NF-kB, NFAT, AP-2 binding site, the c/EBP site, and the CRE site that binds the cyclic AMP response element binding protein (CREB) transcription factor. The NF-kB sites play a significant role in the up-regulation of the COX-2 gene since this transcription factor can be activated through several signaling pathways including those used by IL-1 and TNF-alpha.

There are many natural compounds that have now been studied for their ability to inhibit the production of PGE-2 as well as other inflammatory mediators in human skin cells. Many of these are polyphenolic compounds with pronounced antioxidant activity, and it is likely that they exert their anti-inflammatory effects by blocking ROS production, which prevents the activation of ROS-induced signaling pathways [181-183].

Over 100 natural compounds have been shown to have some ability to block the production of PGE-2, many by inhibiting COX-2 gene expression, and others by acting as a COX-2 inhibitor [184-188]. As discussed previously, the PGE-2 synthesis pathway involves three steps: (1) release of arachidonic acid from phospholipids by the action of phospholipase A2, (2) the conversion of arachidonic acid to PGH2 by COX-1 and COX-2, and (3) the conversion of PGH2 to PGE-2 by PGE synthase (PGES). Pro-inflammatory events can increase the expression of the enzymes that control each of these steps. Exposure of keratinocytes, fibroblasts or immune cells to such stimuli as UVB radiation, IL-1, ROS, or Lipopolysaccharide (LPS) can result in increased COX-2 gene expression, as well as 
increased activity of the genes for PGES and PLA2 [83,95]. By blocking the signaling pathway that leads to activation of transcription factors, particularly NF-kB that regulates these genes, natural anti-inflammatory compounds can block not only COX-2 expression, but expression of PGES [83] and/or cPLA2 [96,189]. A few examples of some natural compounds that block PGE-2 production, as well as other inflammatory mediators, are discussed below:

- Parthenolide, a sesquiterpene lactone found in the commonly used herb, Feverfew, has been shown to block NF-kB regulated genes and inhibits the expression of MMP-1 $[190,191]$. In addition, by blocking NF-kB activation, parthenolide can inhibit COX-2 gene expression [192]. There is also evidence from the UVB mouse model, that oral treatment of irradiated mice with parthenolide can reduce the number of papillomas induced by UVB treatment [193].

- Resveratrol, a polyphenol found in red wine, has considerable anti-inflammatory activity, and can block the increase in COX-2 and PGE-2 levels induced by UVR, as well as by pollutants [194]. Resveratrol can also block the increase in COX-2 in mice treated with chemical carcinogens [195,196]. It has been shown to block MMP-1 expression [194,197], and NF-kB activation [198]. In addition, the analogue of resveratrol, pterostilbene, can inhibit COX-2 in mouse skin and prevent tumor formation in DMBA-treated mice by inhibiting both NF-kB and MAPK signaling pathways $[199,200]$.

- Green tea, and more specifically, Epigallocatechin-3-gallate (EGCG) from green tea, has been widely studied for its antioxidant, anti-inflammatory, anti-cancer, and anti-aging properties, but the data is conflicting and the overall benefits of EGCG are not clear. In human studies, topical application of EGCG before UV irradiation decreased the UVR induction of ROS and inhibited the infiltration of monocytes into the skin [201]. However, oral supplements containing green tea were ineffective in protecting skin from UVR damage [188]. Studies with human keratinocytes treated with airborne pollutants (PM10), showed that EGCG blocked the pollutant induced increase in NADH oxidases, IL-1, TNF-alpha, IL-8, and MMP-1 [202]. In other studies, EGCG reduced the UVR-induced increase in COX-2 in human keratinocytes, but had the opposite effect on human fibroblast cultures, where it increased the expression of both COX-2 and MMP-1 [203]. In studies with skin equivalent cell culture models, EGCG was found to decrease MMP-1 expression and increase TIMP-1, although the effect was not pronounced [204]. Finally, in studies with human fibroblast cell cultures, EGCG exerted a pronounced down-regulation (40\% reduction) in collagen I synthesis [205]. These contradictory findings suggest that EGCG may not be an appropriate ingredient to use in topical products designed to address photoaged or chronically aged skin.

- Aloe Vera extracts are found in many topical products that make marketing claims for helping to reduce inflammation and discomfort from sunburns and inflammatory skin problems. However, there are actually very few scientific studies that have assessed the ability of aloe to suppress inflammatory mediator production in skin. Aloe Vera contains two polyphenolic compounds, Aloin and Aloe-emodin, that are thought to account for the anti-inflammatory effects of the plant. In studies with mouse macrophage cultures induced by LPS (lipopolysaccharide) to produce inflammatory mediators, Aloe-emodin, but not Aloin was found to block COX-2 mRNA expression [206]. In vivo studies using the hairless mouse model showed that a topical Aloe Vera gel extract could reduce the level of MMPs expressed in skin in response to UVB treatment. The effect of this extract on COX-2 levels in UVB-treated skin was not examined in this study [207].

- Other natural compounds that are found in dietary supplements as well as in skin care products, and which have been shown to block either cytokine mediated or UVB-induced COX-2 expression in fibroblasts and/or keratinocytes are: apigenin [186,208], licochalcone [209], salidroside [210], eupafolin [211], CoQ10 [212], delphinidin (from grapes, cranberries) [213], quercetin [187], orange peel extract [214], ferulic acid [215], and luteolin [216].

Since the production of inflammatory mediators such as PGE-2, TNF-alpha and IL-1, either produced in the skin from sun exposure, or increased in the skin due to natural aging (smoldering 
inflammation), causes a variety of aging events including suppressing collagen synthesis, while concurrently increasing the production of MMPs, it seems likely that the daily topical use of formulations containing one or more of these natural anti-inflammatory compounds would help retard the skin aging process. In addition, it is also possible that the same natural compounds that block the expression of inflammatory genes, might directly stimulate genes involved in matrix building, such as collagen I, elastin, and hyaluronic acid synthase. For example, since the collagen I (COL1A1) gene promoter contains a region that NF-kB interacts with (but not an NF-kB consensus sequence) to inhibit gene activity [217], natural compounds that can block the activation of NF-kB, should be able to help maintain the transcriptional activity of the collagen gene and therefore further retard the skin aging process. Evidence that this is indeed the case has been presented in a clinical study that tested the effect of topically administered 4-hexyl-1,3-phenylenediol, an NF-kB inhibitor on photo-damaged skin. After eight weeks of use, patients being treated with the NF-kB inhibitor showed significant improvement in crow's feet fine lines, cheek wrinkles, age spots, mottled pigmentation and radiance [218]. A role for NF-kB in contributing to chronological aging has been demonstrated in studies with fibroblasts obtained from donors over the age of 50 . These cells showed increased basal NF-kB activity, consistent with a slow increase in inflammation that occurs in aging skin. Treatment of these fibroblasts with 4-hexyl-1,3-phenylenediol, increased the expression of extracellular matrix (ECM) genes [218].

Although it would seem reasonable to assume that compounds that can inhibit signaling pathways that activate inflammatory genes should be able to increase the expression of beneficial genes, like the collagen gene in skin cells, unfortunately, this is not always the case. As discussed above, while EGCG (epigallocatechin-3-gallate) has some anti-inflammatory activity, it also decreases the level of type I collagen [205], and stimulates MMP-1 expression [203]. Quercetin, which blocks the production of many inflammatory mediators by inhibiting NF-kB, causes a decrease in mRNA levels for collagen I and III [219]. However, even if many natural anti-inflammatory compounds do not directly stimulate collagen gene activity, many block the expression of MMPs, and this alone will help prevent damage to the dermal matrix.

\subsection{Developing Effective Topical Products to Block PGE-2 in Skin}

Although many natural compounds, including curcumin and resveratrol, have anti-inflammatory activities that would be excellent for reducing skin inflammation and for either arresting, retarding, or even reversing the aging process, whether or not these, or other natural compounds, will prove to be effective when formulated into topical products depends on the compound meeting seven criteria:

- Anti-inflammatory compounds should block the production and / or action of PGE-2 as well as other skin aging inflammatory mediators, such as IL-1 and TNF-alpha.

- Compounds must have a molecular weight less than 500 Daltons, which is the upper limit for penetration through the stratum corneum.

- For skin penetration, compounds should have a $\log P$ (partition coefficient) value between 1 and 3 .

- Compounds must be formulated at a high enough concentration to provide bioactivity when applied topically.

- Compounds must be chemically stable when formulated into topical products.

- Formulations should deliver compounds into the skin at a rate that provides benefits (e.g., blocking MMPs) for many hours after a single application.

- Compounds should be colorless and odorless.

Of the criteria listed above, two deserve additional comment. In regard to the size limitation for topically delivered compounds, a seminal paper published over 18 years ago showed convincingly that chemical compounds with a molecular weight under 500 Daltons could penetrate transcutaneously, but that compounds larger than this are unable to penetrate through the fairly impermeable stratum corneum [220]. This observation has proven to be correct throughout the years, and for this reason, 
topical drugs are based on small molecules. Given this inflexible rule, any natural compound that shows excellent anti-inflammatory properties will only be effective topically if its size is under 500 Daltons. In addition to the size restriction for effective skin penetration, natural anti-inflammatory compounds should, ideally, have a $\log \mathrm{P}$ value between 1 and 3 [221,222]. The partition coefficient, $\log \mathrm{P}$, refers to the relative solubility of a particular compound in water and octanol. As octanol and water are immiscible, the distribution of a compound between these two phases is a good approximation of the partitioning between the cytosol and lipid membranes of living systems. Since the stratum corneum has a high content of lipids, any compound that is more soluble in octanol than water $(\log P \geq 1)$ can penetrate the stratum corneum more easily than a water soluble compound. However, if the $\operatorname{LogP}$ is too high, the compound is so non-polar that it cannot move into the deeper, more aqueous regions of the skin. A good example of compound that is not a good choice for topical development is CoQ10. This antioxidant has a $\log \mathrm{P}$ of 19.4 which makes it a poor candidate for topical formulation development. On the other hand, curcumin, with a molecular weight of $368 \mathrm{~g} / \mathrm{mol}$ and a $\log \mathrm{P}$ of 3.2 is much more likely to penetrate through the stratum corneum and enter the lower layers of the skin. Unfortunately, its bright yellow color and relative instability in water based formulations reduces its usefulness in topical products.

When all seven of these criteria are taken into consideration, many natural anti-inflammatory compounds are not ideal candidates for development into topical formulations. Many of the most potent natural anti-inflammatory compounds, such as curcumin, with its bright yellow stains the skin with an undesirable color. Many other natural compounds are unstable when formulated into a lotion or cream and break down in days or weeks. Some natural compounds are either near the upper limit of size that can penetrate through the stratum corneum (CoQ10, EGCG) or have a partition coefficient value that is not ideal for skin penetration ( $\operatorname{coQ} 10: \log \mathrm{P}=20$; alpha tocopherol; $\log \mathrm{P}=10$ ). Even though many compounds do not meet the criteria, others like ferulic acid and tetrahydrocurcumin do satisfy the criteria, and have been incorporated into topical formulations [223].

Even though a compound satisfies the seven criteria listed above, the only way to show that a "natural anti-inflammatory" will be effective when applied topically is to actually build the formulation and test it clinically. The steps to building an effective topical product involve: (1) determining the optimum amount of "bioactive" to add to the formulation, (2) determining the solubility and stability of the anti-inflammatory compound in acceptable formulation solvents, (3) preparing prototype formulations that are physically stable and which maintain biological activity of the compound, (4) testing the prototype formulation by Franz cell percutaneous absorption analysis to determine the rate and amount of compound that can penetrate into human skin [224,225], and finally (5) testing the formulation clinically. If one assumes that a formulation can be engineered to deliver $2 \%$ to $5 \%$ of a finite applied dose of across the stratum corneum and down to the cells in the epidermis and dermis, then only $1 / 20$ th of whatever anti-inflammatory active is in the product is ever going to get past the stratum corneum and down into the dermis or even the lower part of the epidermis. Therefore, for example, if cell culture studies show that an active completely blocks PGE-2 production in fibroblasts in culture when used at $0.01 \%$, then in theory, to be effective when applied topically, the formulation should contain 20 times this amount of active, or $0.2 \%$. However, there is another variable that must be considered. In cell culture studies the candidate "active" being studied has nowhere to go but remain in the culture medium for $24 \mathrm{~h}$ and during this time it will slowly move across cell membranes into the cell where it can block inflammatory signaling pathways. When applied to the skin, however, the compound is going to diffuse freely throughout the epidermis and dermis and will only have a limited opportunity to be taken up by the cells in the skin. Therefore, for "bioactives" that must either interact with a target cell's membrane receptors or must pass across the surface membrane and enter the target cell (fibroblast or keratinocytes) to exert their effects, the concentration of the natural active in the final formulation will likely have to be increased by another 10 fold, making the concentration $2 \%$ in the final product. By following these formulations guidelines, it is possible to develop topical products that deliver enough of the natural anti-inflammatory compound into the skin to arrest both 
"inflammaging" events as well as inflammation from sun exposure, and by doing so reduce the skin aging process and risk of skin cancer.

\section{Conclusions}

The role of inflammation in skin damage and skin aging is well-known, and it is clear that blocking both the chronic inflammation caused by sun exposure, as well as the increasing level of "smoldering inflammation" that occurs naturally with age, will help reduce the visible signs of aging. Of the inflammatory mediators known to damage and age skin, one of the worst is PGE-2. There are many natural compounds that can block the production of PGE-2 in skin cells, and some of these have already been incorporated into topical products. Given the extent of skin damage and aging caused by PGE-2 and the fact that the levels of this prostaglandin increase with age, even in sun-protected skin, it seems logical that skin care (and sun care) products should be developed with ingredients that can prevent an increase in PGE-2 in the skin. If products can be developed that contain natural compounds to block PGE-2 production in the skin, one can then ask two questions:

1. If consumers in their teens start using products that lower PGE-2 levels, will their skin look noticeably younger as they age, even if they continue to spend time in the sun, and

2. If, at an early age, consumers start using skin care and sun care products that block PGE-2, will they ever get skin cancer or even develop actinic keratosis, even in their later years, and even if they spend time outdoors?

It is interesting to speculate that the visible aging process as well as the incidence of skin cancer will drop dramatically simply from the daily use of products that block the production and/or action of PGE-2.

Funding: It was supportedF by DermaMedics, LLC. There was no grant money. It was just part of the company R\&D operations.

Conflicts of Interest: Fuller has ownership in DermaMedics.

\section{References}

1. Debacq-Chainiaux, F.; Leduc, C.; Verbeke, A.; Toussaint, O. UV, stress and aging. Dermato-Endocrinology 2012, 4, 236-240. [CrossRef]

2. Farage, M.A.; Miller, K.W.; Elsner, P.; Maibach, H.I. Intrinsic and extrinsic factors in skin ageing: A review. Int. J. Cosmet. Sci. 2008, 30, 87-95. [CrossRef]

3. Tobin, D.J. Introduction to skin aging. J. Tissue Viability 2017, 26, 37-46. [CrossRef]

4. Farage, M.A.; Miller, K.W.; Elsner, P.; Maibach, H.I. Characteristics of the Aging Skin. Adv. Wound Care 2013, 2, 5-10. [CrossRef]

5. Weihermann, A.C.; Lorencini, M.; Brohem, C.A.; de Carvalho, C.M. Elastin structure and its involvement in skin photoageing. Int. J. Cosmet. Sci. 2017, 39, 241-247. [CrossRef]

6. Seleit, I.; Bakry, O.A.; El Repey, H.S.; Ali, R. Intrinsic versus Extrinsic Aging: A Histopathological, Morphometric and Immunohistochemical Study of Estrogen Receptor $\beta$ and Androgen Receptor. Skin Pharmacol. Physiol. 2016, 29, 178-189. [CrossRef]

7. Poljšak, B.; Dahmane, R.G.; Godić, A. Intrinsic skin aging: The role of oxidative stress. Acta Dermatovenerol. Alp. Pannonica Adriat. 2012, 21, 33-36.

8. Fang, J.-Y.; Wang, P.-W.; Huang, C.-H.; Chen, M.-H.; Wu, Y.-R.; Pan, T.-L. Skin aging caused by intrinsic or extrinsic processes characterized with functional proteomics. Proteomics 2016, 16, 2718-2731. [CrossRef]

9. Franceschi, C.; Campisi, J. Chronic Inflammation (Inflammaging) and Its Potential Contribution to Age-Associated Diseases. J. Gerontol. A Biol. Sci. Med. Sci. 2014, 69, S4-S9. [CrossRef]

10. Uitto, J. The role of elastin and collagen in cutaneous aging: Intrinsic aging versus photoexposure. J. Drugs Dermatol. 2008, 7, s12-s16.

11. Sárdy, M. Role of Matrix Metalloproteinases in Skin Ageing. Connect. Tissue Res. 2009, 50, 132-138. [CrossRef] 
12. Rinnerthaler, M.; Bischof, J.; Streubel, M.; Trost, A.; Richter, K. Oxidative Stress in Aging Human Skin. Biomolecules 2015, 5, 545-589. [CrossRef]

13. Kossodo, S.; Wong, W.-R.; Simon, G.; Kochevar, I.E. Effects of UVR and UVR-induced Cytokines on Production of Extracellular Matrix Proteins and Proteases by Dermal Fibroblasts Cultured in Collagen Gels. Photochem. Photobiol. 2004, 79, 86-93. [CrossRef]

14. Sauvaigo, S.; Bonnet-Duquennoy, M.; Odin, F.; Hazane-Puch, F.; Lachmann, N.; Bonté, F.; Kurfürst, R.; Favier, A. DNA repair capacities of cutaneous fibroblasts: Effect of sun exposure, age and smoking on response to an acute oxidative stress. Br. J. Dermatol. 2007, 157, 26-32. [CrossRef]

15. Kim, C.; Ryu, H.-C.; Kim, J.-H. Low-dose UVB irradiation stimulates matrix metalloproteinase-1 expression via a BLT2-linked pathway in HaCaT cells. Exp. Mol. Med. 2010, 42, 833-841. [CrossRef]

16. Quan, T.; Qin, Z.; Xia, W.; Shao, Y.; Voorhees, J.J.; Fisher, G.J. Matrix-Degrading Metalloproteinases in Photoaging. J. Investig. Dermatol. Symp. Proc. 2009, 14, 20-24. [CrossRef]

17. Kim, J.; Kim, M.-B.; Yun, J.G.; Hwang, J.K. Protective Effects of Standardized Siegesbeckia glabrescens Extract and Its Active Compound Kirenol against UVB-Induced Photoaging through Inhibition of MAPK/NF- $\mathrm{kB}$ Pathways. J. Microbiol. Biotechnol. 2017, 27, 242-250. [CrossRef]

18. Tewari, A.; Grys, K.; Kollet, J.; Sarkany, R.; Young, A.R. Upregulation of MMP12 and Its Activity by UVA1 in Human Skin: Potential Implications for Photoaging. J. Investig. Dermatol. 2014, 134, 2598-2609. [CrossRef]

19. Dai, G.; Freudenberger, T.; Zipper, P.; Melchior, A.; Grether-Beck, S.; Rabausch, B.; de Groot, J.; Twarock, S.; Hanenberg, H.; Homey, B.; et al. Chronic ultraviolet B irradiation causes loss of hyaluronic acid from mouse dermis because of down-regulation of hyaluronic acid synthases. Am. J. Pathol. 2007, 171, 1451-1461. [CrossRef]

20. Shin, J.-E.; Oh, J.-H.; Kim, Y.K.; Jung, J.-Y.; Chung, J.H. Transcriptional Regulation of Proteoglycans and Glycosaminoglycan Chain-synthesizing Glycosyltransferases by UV Irradiation in Cultured Human Dermal Fibroblasts. J. Korean Med. Sci. 2011, 26, 417-424. [CrossRef]

21. Kurdykowski, S.; Mine, S.; Bardey, V.; Danoux, L.; Jeanmaire, C.; Pauly, G.; Brabencova, E.; Wegrowski, Y.; Maquart, F.X. Ultraviolet-B Irradiation Induces Differential Regulations of Hyaluronidase Expression and Activity in Normal Human Keratinocytes: Photochemistry and Photobiology. Photochem. Photobiol. 2011, 87, 1105-1112. [CrossRef]

22. Oh, J.-H.; Kim, Y.K.; Jung, J.-Y.; Shin, J.; Kim, K.H.; Cho, K.H.; Eun, H.C.; Chung, J.H. Intrinsic aging- and photoaging-dependent level changes of glycosaminoglycans and their correlation with water content in human skin. J. Dermatol. Sci. 2011, 62, 192-201. [CrossRef]

23. Glady, A.; Tanaka, M.; Moniaga, C.S.; Yasui, M.; Hara-Chikuma, M. Involvement of NADPH oxidase 1 in UVB-induced cell signaling and cytotoxicity in human keratinocytes. Biochem. Biophys. Rep. 2018, 14, 7-15. [CrossRef]

24. Kammeyer, A.; Luiten, R.M. Oxidation events and skin aging. Ageing Res. Rev. 2015, 21, 16-29. [CrossRef]

25. Kozina, L.S.; Borzova, I.V.; Arutiunov, V.A.; Ryzhak, G.A. Role of oxidative stress in skin aging. Adv. Gerontol. 2013, 3, 18-22. [CrossRef]

26. Fisher, G.J.; Kang, S.; Varani, J.; Bata-Csorgo, Z.; Wan, Y.; Datta, S.; Voorhees, J.J. Mechanisms of photoaging and chronological skin aging. Arch. Dermatol. 2002, 138, 1462-1470. [CrossRef]

27. Valencia, A.; Kochevar, I.E. Nox1-Based NADPH Oxidase Is the Major Source of UVA-Induced Reactive Oxygen Species in Human Keratinocytes. J. Investig. Dermatol. 2008, 128, 214-222. [CrossRef]

28. Beak, S.M.; Lee, Y.S.; Kim, J.-A. NADPH oxidase and cyclooxygenase mediate the ultraviolet B-induced generation of reactive oxygen species and activation of nuclear factor- $\mathrm{kB}$ in HaCaT human keratinocytes. Biochimie 2004, 86, 425-429. [CrossRef]

29. Xu, Y.; Shao, Y.; Zhou, J.; Voorhees, J.J.; Fisher, G.J. Ultraviolet irradiation-induces epidermal growth factor receptor (EGFR) nuclear translocation in human keratinocytes. J. Cell. Biochem. 2009, 107, 873-880. [CrossRef]

30. Huang, R.P.; Wu, J.X.; Fan, Y.; Adamson, E.D. UV activates growth factor receptors via reactive oxygen intermediates. J. Cell Biol. 1996, 133, 211-220. [CrossRef]

31. Tober, K.L.; Thomas-Ahner, J.M.; Kusewitt, D.F.; Oberyszyn, T.M. Effects of UVB on E Prostanoid Receptor Expression in Murine Skin. J. Investig. Dermatol. 2007, 127, 214-221. [CrossRef] 
32. Soontrapa, K.; Honda, T.; Sakata, D.; Yao, C.; Hirata, T.; Hori, S.; Matsuoka, T.; Kita, Y.; Shimizu, T.; Kabashima, K.; et al. Prostaglandin E2-prostoglandin E receptor subtype 4 (EP4) signaling mediates UV irradiation-induced systemic immunosuppression. Proc. Natl. Acad. Sci. USA 2011, 108, 6668-6673. [CrossRef]

33. Muthusamy, V.; Piva, T.J. The UV response of the skin: A review of the MAPK, NFkB and TNF $\alpha$ signal transduction pathways. Arch. Dermatol. Res. 2010, 302, 5-17. [CrossRef]

34. Wan, Y.S.; Wang, Z.Q.; Voorhees, J.; Fisher, G. EGF receptor crosstalks with cytokine receptors leading to the activation of c-Jun kinase in response to UV irradiation in human keratinocytes. Cell. Signal. 2001, 13, 139-144. [CrossRef]

35. Blanton, R.A.; Kupper, T.S.; McDougall, J.K.; Dower, S. Regulation of interleukin 1 and its receptor in human keratinocytes. Proc. Natl. Acad. Sci. USA 1989, 86, 1273-1277. [CrossRef]

36. López-Camarillo, C.; Ocampo, E.A.; Casamichana, M.L.; Pérez-Plasencia, C.; Alvarez-Sánchez, E.; Marchat, L.A. Protein kinases and transcription factors activation in response to UV-radiation of skin: Implications for carcinogenesis. Int. J. Mol. Sci. 2012, 13, 142-172. [CrossRef]

37. Rosette, C.; Karin, M. Ultraviolet light and osmotic stress: Activation of the JNK cascade through multiple growth factor and cytokine receptors. Science 1996, 274, 1194-1197. [CrossRef]

38. Peus, D.; Meves, A.; Vasa, R.A.; Beyerle, A.; O’Brien, T.; Pittelkow, M.R. H2O2 is required for UVB-induced EGF receptor and downstream signaling pathway activation. Free Radic. Biol. Med. 1999, 27, 1197-1202. [CrossRef]

39. Madson, J.G.; Hansen, L.A. Multiple mechanisms of Erbb2 action after ultraviolet irradiation of the skin. Mol. Carcinog. 2007, 46, 624-628. [CrossRef]

40. Son, Y.; Cheong, Y.-K.; Kim, N.-H.; Chung, H.-T.; Kang, D.G.; Pae, H.-O. Mitogen-Activated Protein Kinases and Reactive Oxygen Species: How Can ROS Activate MAPK Pathways? J. Signal Transduct. 2011, 2011, 792639. [CrossRef]

41. Finkel, T. Signal transduction by reactive oxygen species. J. Cell Biol. 2011, 194, 7-15. [CrossRef]

42. Chaiprasongsuk, A.; Lohakul, J.; Soontrapa, K.; Sampattavanich, S.; Akarasereenont, P.; Panich, U. Activation of Nrf2 Reduces UVA-Mediated MMP-1 Upregulation via MAPK/AP-1 Signaling Cascades: The Photoprotective Effects of Sulforaphane and Hispidulin. J. Pharmacol. Exp. Ther. 2017, 360, 388-398. [CrossRef]

43. Ghosh, A.K.; Yuan, W.; Mori, Y.; Varga, J. Smad-dependent stimulation of type I collagen gene expression in human skin fibroblasts by TGF-beta involves functional cooperation with p300/CBP transcriptional coactivators. Oncogene 2000, 19, 3546-3555. [CrossRef]

44. Chung, K.Y.; Agarwal, A.; Uitto, J.; Mauviel, A. An AP-1 binding sequence is essential for regulation of the human alpha2(I) collagen (COL1A2) promoter activity by transforming growth factor-beta. J. Biol. Chem. 1996, 271, 3272-3278. [CrossRef]

45. Marrot, L. Pollution and Sun Exposure: A Deleterious Synergy. Mechanisms and Opportunities for Skin Protection. Curr. Med. Chem. 2017. [CrossRef]

46. Crisan, M.; Taulescu, M.; Crisan, D.; Cosgarea, R.; Parvu, A.; Cãtoi, C.; Drugan, T. Expression of Advanced Glycation End-Products on Sun-Exposed and Non-Exposed Cutaneous Sites during the Ageing Process in Humans. PLoS ONE 2013, 8, e75003. [CrossRef]

47. Salminen, A.; Huuskonen, J.; Ojala, J.; Kauppinen, A.; Kaarniranta, K.; Suuronen, T. Activation of innate immunity system during aging: NF-kB signaling is the molecular culprit of inflamm-aging. Ageing Res. Rev. 2008, 7, 83-105. [CrossRef]

48. Liu, Q.; Zhang, D.; Hu, D.; Zhou, X.; Zhou, Y. The role of mitochondria in NLRP3 inflammasome activation. Mol. Immunol. 2018, 103, 115-124. [CrossRef]

49. Martien, S.; Pluquet, O.; Vercamer, C.; Malaquin, N.; Martin, N.; Gosselin, K.; Pourtier, A.; Abbadie, C. Cellular senescence involves an intracrine prostaglandin $\mathrm{E}_{2}$ pathway in human fibroblasts. Biochim. Biophys. Acta 2013, 1831, 1217-1227. [CrossRef]

50. Fossel, M. Cell senescence in human aging and disease. Ann. N. Y. Acad. Sci. 2002, 959, 14-23. [CrossRef]

51. Toutfaire, M.; Bauwens, E.; Debacq-Chainiaux, F. The impact of cellular senescence in skin ageing: A notion of mosaic and therapeutic strategies. Biochem. Pharmacol. 2017, 142, 1-12. [CrossRef] 
52. Wang, X.; Bi, Z.; Chu, W.; Wan, Y. IL-1 receptor antagonist attenuates MAP kinase/AP-1 activation and MMP1 expression in UVA-irradiated human fibroblasts induced by culture medium from UVB-irradiated human skin keratinocytes. Int. J. Mol. Med. 2005, 16, 1117-1124. [CrossRef]

53. Keshet, Y.; Seger, R. The MAP kinase signaling cascades: A system of hundreds of components regulates a diverse array of physiological functions. Methods Mol. Biol. 2010, 661, 3-38.

54. Sun, Y.; Liu, W.-Z.; Liu, T.; Feng, X.; Yang, N.; Zhou, H.-F. Signaling pathway of MAPK/ERK in cell proliferation, differentiation, migration, senescence and apoptosis. J. Recept. Signal Transduct. Res. 2015, 35, 600-604. [CrossRef]

55. Chang, L.; Karin, M. Mammalian MAP kinase signalling cascades. Nature 2001, 410, 37-40. [CrossRef]

56. Hayden, M.S.; Ghosh, S. Shared principles in NF-kappaB signaling. Cell 2008, 132, 344-362. [CrossRef]

57. Tak, P.P.; Firestein, G.S. NF-kappaB: A key role in inflammatory diseases. J. Clin. Investig. 2001, 107, 7-11. [CrossRef]

58. Hogan, P.G.; Chen, L.; Nardone, J.; Rao, A. Transcriptional regulation by calcium, calcineurin, and NFAT. Genes Dev. 2003, 17, 2205-2232. [CrossRef]

59. Mancini, M.; Toker, A. NFAT proteins: Emerging roles in cancer progression. Nat. Rev. Cancer 2009, 9, 810-820. [CrossRef]

60. Kasza, A. IL-1 and EGF regulate expression of genes important in inflammation and cancer. Cytokine 2013, 62, 22-33. [CrossRef]

61. Trefzer, U.; Brockhaus, M.; Lötscher, H.; Parlow, F.; Budnik, A.; Grewe, M.; Christoph, H.; Kapp, A.; Schöpf, E.; Luger, T.A. The 55-kD tumor necrosis factor receptor on human keratinocytes is regulated by tumor necrosis factor-alpha and by ultraviolet B radiation. J. Clin. Investig. 1993, 92, 462-470. [CrossRef]

62. Takii, T.; Akahoshi, T.; Kato, K.; Hayashi, H.; Marunouchi, T.; Onozaki, K. Interleukin-1 up-regulates transcription of its own receptor in a human fibroblast cell line TIG-1: Role of endogenous PGE2 and cAMP. Eur. J. Immunol. 1992, 22, 1221-1227. [CrossRef]

63. El-Abaseri, T.B.; Hammiller, B.; Repertinger, S.K.; Hansen, L.A. The Epidermal Growth Factor Receptor Increases Cytokine Production and Cutaneous Inflammation in Response to Ultraviolet Irradiation. ISRN Dermatol. 2013, 2013, 848705. [CrossRef]

64. Gupta, S.C.; Kunnumakkara, A.B.; Aggarwal, S.; Aggarwal, B.B. Inflammation, a Double-Edge Sword for Cancer and Other Age-Related Diseases. Front. Immunol. 2018, 9, 2160. [CrossRef]

65. Li, Y.; Lei, D.; Swindell, W.R.; Xia, W.; Weng, S.; Fu, J.; Worthen, C.A.; Okubo, T.; Johnston, A.; Gudjonsson, J.E.; et al. Age-Associated Increase in Skin Fibroblast-Derived Prostaglandin $E_{2}$ Contributes to Reduced Collagen Levels in Elderly Human Skin. J. Investig. Dermatol. 2015, 135, 2181-2188. [CrossRef]

66. Habib, M.A.; Salem, S.A.M.; Hakim, S.A.; Shalan, Y.A.M. Comparative immunohistochemical assessment of cutaneous cyclooxygenase-2 enzyme expression in chronological aging and photoaging: COX-2 in chronological aging and photoaging. Photodermatol. Photoimmunol. Photomed. 2014, 30, 43-51. [CrossRef]

67. Surowiak, P.; Gansukh, T.; Donizy, P.; Halon, A.; Rybak, Z. Increase in cyclooxygenase-2 (COX-2) expression in keratinocytes and dermal fibroblasts in photoaged skin. J. Cosmet. Dermatol. 2014, 13, 195-201. [CrossRef]

68. Ashida, M.; Bito, T.; Budiyanto, A.; Ichihashi, M.; Ueda, M. Involvement of EGF receptor activation in the induction of cyclooxygenase-2 in HaCaT keratinocytes after UVB. Exp. Dermatol. 2003, 12, 445-452. [CrossRef]

69. Karin, M.; Liu, Z.; Zandi, E. AP-1 function and regulation. Curr. Opin. Cell Biol. 1997, 9, 240-246. [CrossRef]

70. Bachelor, M.A.; Cooper, S.J.; Sikorski, E.T.; Bowden, G.T. Inhibition of p38 mitogen-activated protein kinase and phosphatidylinositol 3-kinase decreases UVB-induced activator protein-1 and cyclooxygenase-2 in a SKH-1 hairless mouse model. Mol. Cancer Res. MCR 2005, 3, 90-99. [CrossRef]

71. Kang, Y.-J.; Mbonye, U.R.; DeLong, C.J.; Wada, M.; Smith, W.L. Regulation of intracellular cyclooxygenase levels by gene transcription and protein degradation. Prog. Lipid Res. 2007, 46, 108-125. [CrossRef]

72. Flockhart, R.J.; Diffey, B.L.; Farr, P.M.; Lloyd, J.; Reynolds, N.J. NFAT regulates induction of COX-2 and apoptosis of keratinocytes in response to ultraviolet radiation exposure. FASEB J. 2008, 22, 4218-4227. [CrossRef]

73. Båge, T.; Lindberg, J.; Lundeberg, J.; Modéer, T.; Yucel-Lindberg, T. Signal pathways JNK and NF- $\mathrm{kB}$, identified by global gene expression profiling, are involved in regulation of TNF $\alpha$-induced mPGES-1 and COX-2 expression in gingival fibroblasts. BMC Genomics 2010, 11, 241. [CrossRef] 
74. Wen, K.-C.; Fan, P.-C.; Tsai, S.-Y.; Shih, I.-C.; Chiang, H.-M. Ixora parviflora Protects against UVB-Induced Photoaging by Inhibiting the Expression of MMPs, MAP Kinases, and COX-2 and by Promoting Type I Procollagen Synthesis. Evid. Based Complement. Alternat. Med. 2012, 2012, 417346. [CrossRef]

75. Mazière, C.; Morlière, P.; Louandre, C.; Conte, M.-A.; Gomilla, C.; Santus, R.; Antonicelli, F.; Hornebeck, W.; Mazière, J.-C. Low UVA doses activate the transcription factor NFAT in human fibroblasts by a calcium-calcineurin pathway. Free Radic. Biol. Med. 2005, 39, 1629-1637. [CrossRef]

76. Zucali, J.R.; Dinarello, C.A.; Oblon, D.J.; Gross, M.A.; Anderson, L.; Weiner, R.S. Interleukin 1 stimulates fibroblasts to produce granulocyte-macrophage colony-stimulating activity and prostaglandin $\mathrm{E}_{2}$. J. Clin. Investig. 1986, 77, 1857-1863. [CrossRef]

77. Kida, Y.; Kobayashi, M.; Suzuki, T.; Takeshita, A.; Okamatsu, Y.; Hanazawa, S.; Yasui, T.; Hasegawa, K. Interleukin-1 stimulates cytokines, prostaglandin $\mathrm{E}$ and matrix metalloproteinase-1 production via activation of MAPK/AP-1 and NF-кB in human gingival fibroblasts. Cytokine 2005, 29, 159-168. [CrossRef]

78. Bagga, D.; Wang, L.; Farias-Eisner, R.; Glaspy, J.A.; Reddy, S.T. Differential effects of prostaglandin derived from -6 and -3 polyunsaturated fatty acids on COX-2 expression and IL-6 secretion. Proc. Natl. Acad. Sci. USA 2003, 100, 1751-1756. [CrossRef]

79. Ansari, K.M.; Sung, Y.M.; He, G.; Fischer, S.M. Prostaglandin receptor EP2 is responsible for cyclooxygenase-2 induction by prostaglandin $\mathrm{E}_{2}$ in mouse skin. Carcinogenesis 2007, 28, 2063-2068. [CrossRef]

80. Kim, B.-H.; Oh, I.; Kim, J.-H.; Jeon, J.-E.; Jeon, B.; Shin, J.; Kim, T.-Y. Anti-inflammatory activity of compounds isolated from Astragalus sinicus L. in cytokine-induced keratinocytes and skin. Exp. Mol. Med. 2014, 46, e87. [CrossRef]

81. Seo, S.-H.; Jeong, G.-S. Fisetin inhibits TNF- $\alpha$-induced inflammatory action and hydrogen peroxide-induced oxidative damage in human keratinocyte HaCaT cells through PI3K/AKT/Nrf-2-mediated heme oxygenase-1 expression. Int. Immunopharmacol. 2015, 29, 246-253. [CrossRef]

82. Maldve, R.E.; Kim, Y.; Muga, S.J.; Fischer, S.M. Prostaglandin E(2) regulation of cyclooxygenase expression in keratinocytes is mediated via cyclic nucleotide-linked prostaglandin receptors. J. Lipid Res. 2000, 41, 873-881.

83. Black, A.T.; Gray, J.P.; Shakarjian, M.P.; Mishin, V.; Laskin, D.L.; Heck, D.E.; Laskin, J.D. UVB light upregulates prostaglandin synthases and prostaglandin receptors in mouse keratinocytes. Toxicol. Appl. Pharmacol. 2008, 232, 14-24. [CrossRef]

84. Rijken, F.; Kiekens, R.C.M.; Bruijnzeel, P.L.B. Skin-infiltrating neutrophils following exposure to solar-simulated radiation could play an important role in photoageing of human skin. Br. J. Dermatol. 2005, 152, 321-328. [CrossRef]

85. Su, Y.; Richmond, A. Chemokine Regulation of Neutrophil Infiltration of Skin Wounds. Adv. Wound Care 2015, 4, 631-640. [CrossRef]

86. Ramanan, M.; Doble, M. Transcriptional Regulation of mPGES1 in Cancer: An Alternative Approach to Drug Discovery? Curr. Drug Targets 2017, 18, 119-131. [CrossRef]

87. Páramo, J.A.; Rodríguez, J.A.; Beloqui, O.; Orbe, J. Monocyte cyclooxygenase-2 activity: A new therapeutic target for atherosclerosis? Curr. Drug Targets Cardiovasc. Haematol. Disord. 2005, 5, 303-311. [CrossRef]

88. Cheng, S.-E.; Luo, S.-F.; Jou, M.-J.; Lin, C.-C.; Kou, Y.R.; Lee, I.-T.; Hsieh, H.-L.; Yang, C.-M. Cigarette smoke extract induces cytosolic phospholipase A2 expression via NADPH oxidase, MAPKs, AP-1, and NF-kappaB in human tracheal smooth muscle cells. Free Radic. Biol. Med. 2009, 46, 948-960. [CrossRef]

89. Zhou, X.; Li, D.; Resnick, M.B.; Wands, J.; Cao, W. NADPH Oxidase NOX5-S and Nuclear Factor B1 Mediate Acid-Induced Microsomal Prostaglandin E Synthase-1 Expression in Barrett's Esophageal Adenocarcinoma Cells. Mol. Pharmacol. 2013, 83, 978-990. [CrossRef]

90. Akitake, Y.; Nakatani, Y.; Kamei, D.; Hosokawa, M.; Akatsu, H.; Uematsu, S.; Akira, S.; Kudo, I.; Hara, S.; Takahashi, M. Microsomal prostaglandin E synthase-1 is induced in alzheimer's disease and its deletion mitigates alzheimer's disease-like pathology in a mouse model: mPGES-1 in Alzheimer's Disease. J. Neurosci. Res. 2013, 91, 909-919. [CrossRef]

91. Kojima, F.; Kato, S.; Kawai, S. Prostaglandin E synthase in the pathophysiology of arthritis. Fundam. Clin. Pharmacol. 2005, 19, 255-261. [CrossRef]

92. Koeberle, A.; Laufer, S.A.; Werz, O. Design and Development of Microsomal Prostaglandin $E_{2}$ Synthase-1 Inhibitors: Challenges and Future Directions. J. Med. Chem. 2016, 59, 5970-5986. [CrossRef] 
93. Shekfeh, S.; Çalışkan, B.; Fischer, K.; Yalçın, T.; Garscha, U.; Werz, O.; Banoglu, E. A Multi-step Virtual Screening Protocol for the Identification of Novel Non-acidic Microsomal Prostaglandin $E_{2}$ Synthase-1 (mPGES-1) Inhibitors. ChemMedChem 2018. [CrossRef]

94. Chen, X.; Gresham, A.; Morrison, A.; Pentland, A.P. Oxidative stress mediates synthesis of cytosolic phospholipase A2 after UVB injury. Biochim. Biophys. Acta 1996, 1299, 23-33. [CrossRef]

95. Gresham, A.; Masferrer, J.; Chen, X.; Leal-Khouri, S.; Pentland, A.P. Increased synthesis of high-molecular-weight cPLA2 mediates early UV-induced PGE2 in human skin. Am. J. Physiol.-Cell Physiol. 1996, 270, C1037-C1050. [CrossRef]

96. Lin, C.-C.; Lin, W.-N.; Cho, R.-L.; Wang, C.; Hsiao, L.-D.; Yang, C.-M. TNF- $\alpha$-Induced cPLA 2 Expression via NADPH Oxidase/Reactive Oxygen Species-Dependent NF-кB Cascade on Human Pulmonary Alveolar Epithelial Cells. Front. Pharmacol. 2016, 7, 447. [CrossRef]

97. Sjursen, W.; Brekke, O.L.; Johansen, B. Secretory and cytosolic phospholipase A(2)regulate the long-term cytokine-induced eicosanoid production in human keratinocytes. Cytokine 2000, 12, 1189-1194. [CrossRef]

98. Lee, C.-W.; Lee, I.-T.; Lin, C.-C.; Lee, H.-C.; Lin, W.-N.; Yang, C.-M. Activation and induction of cytosolic

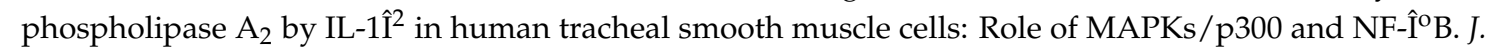
Cell. Biochem. 2010, 109, 1045-1056.

99. Luo, S.-F.; Lin, C.-C.; Chen, H.-C.; Lin, W.-N.; Lee, I.-T.; Lee, C.-W.; Hsiao, L.-D.; Yang, C.-M. Involvement of MAPKs, NF- $\mathrm{BB}$ and p300 co-activator in IL-1 $\beta$-induced cytosolic phospholipase A2 expression in canine tracheal smooth muscle cells. Toxicol. Appl. Pharmacol. 2008, 232, 396-407. [CrossRef]

100. Rundhaug, J.E.; Simper, M.S.; Surh, I.; Fischer, S.M. The role of the EP receptors for prostaglandin $E_{2}$ in skin and skin cancer. Cancer Metastasis Rev. 2011, 30, 465-480. [CrossRef]

101. Kobilka, B.K. G protein coupled receptor structure and activation. Biochim. Biophys. Acta 2007, 1768, $794-807$. [CrossRef]

102. Miller, L.J. G protein-coupled receptor structures, molecular associations, and modes of regulation. Ann. N. Y. Acad. Sci. 2008, 1144, 1-5. [CrossRef]

103. Rosenbaum, D.M.; Rasmussen, S.G.F.; Kobilka, B.K. The structure and function of G-protein-coupled receptors. Nature 2009, 459, 356-363. [CrossRef]

104. Tober, K.L.; Wilgus, T.A.; Kusewitt, D.F.; Thomas-Ahner, J.M.; Maruyama, T.; Oberyszyn, T.M. Importance of the EP1 Receptor in Cutaneous UVB-Induced Inflammation and Tumor Development. J. Investig. Dermatol. 2006, 126, 205-211. [CrossRef]

105. Konger, R.L.; Malaviya, R.; Pentland, A.P. Growth regulation of primary human keratinocytes by prostaglandin E receptor EP2 and EP3 subtypes. Biochim. Biophys. Acta 1998, 1401, 221-234. [CrossRef]

106. Sung, Y.M.; He, G.; Hwang, D.H.; Fischer, S.M. Overexpression of the prostaglandin $\mathrm{E}_{2}$ receptor EP2 results in enhanced skin tumor development. Oncogene 2006, 25, 5507-5516. [CrossRef]

107. Konger, R.L.; Brouxhon, S.; Partillo, S.; VanBuskirk, J.; Pentland, A.P. The EP3 receptor stimulates ceramide and diacylglycerol release and inhibits growth of primary keratinocytes. Exp. Dermatol. 2005, 14, 914-922. [CrossRef]

108. Amano, H.; Ito, Y.; Suzuki, T.; Kato, S.; Matsui, Y.; Ogawa, F.; Murata, T.; Sugimoto, Y.; Senior, R.; Kitasato, H.; et al. Roles of a prostaglandin E-type receptor, EP3, in upregulation of matrix metalloproteinase-9 and vascular endothelial growth factor during enhancement of tumor metastasis. Cancer Sci. 2009, 100, 2318-2324. [CrossRef]

109. Zeng, L.; An, S.; Goetzl, E.J. Regulation of expression of matrix metalloproteinase-9 in early human T cells of the HSB.2 cultured line by the EP3 subtype of prostaglandin $E_{2}$ receptor. J. Biol. Chem. 1996, 271, 27744-27750. [CrossRef]

110. Yokoyama, U.; Iwatsubo, K.; Umemura, M.; Fujita, T.; Ishikawa, Y. The Prostanoid EP4 Receptor and Its Signaling Pathway. Pharmacol. Rev. 2013, 65, 1010-1052. [CrossRef]

111. Konya, V.; Marsche, G.; Schuligoi, R.; Heinemann, A. E-type prostanoid receptor 4 (EP4) in disease and therapy. Pharmacol. Ther. 2013, 138, 485-502. [CrossRef]

112. Tandara, A.A.; Mustoe, T.A. MMP- and TIMP-secretion by human cutaneous keratinocytes and fibroblastsimpact of coculture and hydration. J. Plast. Reconstr. Aesthet. Surg. 2011, 64, 108-116. [CrossRef]

113. Yen, J.-H.; Khayrullina, T.; Ganea, D. PGE2-induced metalloproteinase-9 is essential for dendritic cell migration. Blood 2008, 111, 260-270. [CrossRef] 
114. Steenport, M.; Khan, K.M.F.; Du, B.; Barnhard, S.E.; Dannenberg, A.J.; Falcone, D.J. Matrix Metalloproteinase (MMP)-1 and MMP-3 Induce Macrophage MMP-9: Evidence for the Role of TNF- and Cyclooxygenase-2. J. Immunol. 2009, 183, 8119-8127. [CrossRef]

115. Deshmane, S.L.; Kremlev, S.; Amini, S.; Sawaya, B.E. Monocyte chemoattractant protein-1 (MCP-1): An overview. J. Interferon Cytokine Res. 2009, 29, 313-326. [CrossRef]

116. Kang, J.S.; Kim, H.N.; Jung, D.J.; Kim, J.E.; Mun, G.H.; Kim, Y.S.; Cho, D.; Shin, D.H.; Hwang, Y.-I.; Lee, W.J. Regulation of UVB-Induced IL-8 and MCP-1 Production in Skin Keratinocytes by Increasing Vitamin C Uptake via the Redistribution of SVCT-1 from the Cytosol to the Membrane. J. Investig. Dermatol. 2007, 127, 698-706. [CrossRef]

117. Conti, P.; DiGioacchino, M. MCP-1 and RANTES are mediators of acute and chronic inflammation. Allergy Asthma Proc. 2001, 22, 133-137. [CrossRef]

118. Varga, J.; Diaz-Perez, A.; Rosenbloom, J.; Jimenez, S.A. PGE2 causes a coordinate decrease in the steady state levels of fibronectin and types I and III procollagen mRNAs in normal human dermal fibroblasts. Biochem. Biophys. Res. Commun. 1987, 147, 1282-1288. [CrossRef]

119. Yang, H.H.; Kim, C.; Jung, B.; Kim, K.S.; Kim, J.-R. Involvement of IGF binding protein 5 in prostaglandin E2-induced cellular senescence in human fibroblasts. Biogerontology 2011, 12, 239-252. [CrossRef]

120. Romana-Souza, B.; dos Santos, J.S.; Bandeira, L.G.; Monte-Alto-Costa, A. Selective inhibition of COX-2 improves cutaneous wound healing of pressure ulcers in mice through reduction of iNOS expression. Life Sci. 2016, 153, 82-92. [CrossRef]

121. Denkert, C.; Köbel, M.; Berger, S.; Siegert, A.; Leclere, A.; Trefzer, U.; Hauptmann, S. Expression of cyclooxygenase 2 in human malignant melanoma. Cancer Res. 2001, 61, 303-308.

122. Thompson, E.J.; Gupta, A.; Vielhauer, G.A.; Regan, J.W.; Bowden, G.T. The growth of malignant keratinocytes depends on signaling through the PGE2 receptor EP1. Neoplasia 2001, 3, 402-410. [CrossRef]

123. Bachelor, M.A.; Bowden, G.T. UVA-mediated activation of signaling pathways involved in skin tumor promotion and progression. Semin. Cancer Biol. 2004, 14, 131-138. [CrossRef]

124. Pentland, A.P.; Schoggins, J.W.; Scott, G.A.; Khan, K.N.; Han, R. Reduction of UV-induced skin tumors in hairless mice by selective COX-2 inhibition. Carcinogenesis 1999, 20, 1939-1944. [CrossRef]

125. Surh, I.; Rundhaug, J.; Pavone, A.; Mikulec, C.; Abel, E.; Fischer, S.M. Upregulation of the EP1 receptor for prostaglandin $\mathrm{E}_{2}$ promotes skin tumor progression. Mol. Carcinog. 2011, 50, 458-468. [CrossRef]

126. Rijken, F.; Bruijnzeel, P.L.B. The Pathogenesis of Photoaging: The Role of Neutrophils and Neutrophil-Derived Enzymes. J. Investig. Dermatol. Symp. Proc. 2009, 14, 67-72. [CrossRef]

127. Wong, W.R.; Kossodo, S.; Kochevar, I.E. Influence of cytokines on matrix metalloproteinases produced by fibroblasts cultured in monolayer and collagen gels. J. Formos. Med. Assoc./Taiwan Yi Zhi 2001, 100, 377-382.

128. Zhao, J.; Shu, B.; Chen, L.; Tang, J.; Zhang, L.; Xie, J.; Liu, X.; Xu, Y.; Qi, S. Prostaglandin $E_{2}$ inhibits collagen synthesis in dermal fibroblasts and prevents hypertrophic scar formation in vivo. Exp. Dermatol. 2016, 25, 604-610. [CrossRef]

129. Thampatty, B.P.; Li, H.; Im, H.-J.; Wang, J.H.-C. EP4 receptor regulates collagen type-I, MMP-1, and MMP-3 gene expression in human tendon fibroblasts in response to IL-1 beta treatment. Gene 2007, 386, 154-161. [CrossRef]

130. Hayashi, T.; Nishihira, J.; Koyama, Y.; Sasaki, S.; Yamamoto, Y. Decreased Prostaglandin $E_{2}$ Production by Inflammatory Cytokine and Lower Expression of EP2 Receptor Result in Increased Collagen Synthesis in Keloid Fibroblasts. J. Investig. Dermatol. 2006, 126, 990-997. [CrossRef]

131. Liu, X. Fibrotic Lung Fibroblasts Show Blunted Inhibition by cAMP Due to Deficient cAMP Response Element-Binding Protein Phosphorylation. J. Pharmacol. Exp. Ther. 2005, 315, 678-687. [CrossRef]

132. Takahashi, S.; Inoue, T.; Higaki, M.; Mizushima, Y. Cyclooxygenase inhibitors enhance the production of tissue inhibitor-1 of metalloproteinases (TIMP-1) and pro-matrix metalloproteinase 1 (proMMP-1) in human rheumatoid synovial fibroblasts. Inflamm. Res. 1997, 46, 320-323. [CrossRef] [PubMed]

133. Lee, J.; Banu, S.K.; Subbarao, T.; Starzinski-Powitz, A.; Arosh, J.A. Selective inhibition of prostaglandin $\mathrm{E}_{2}$ receptors EP2 and EP4 inhibits invasion of human immortalized endometriotic epithelial and stromal cells through suppression of metalloproteinases. Mol. Cell. Endocrinol. 2011, 332, 306-313. [CrossRef] [PubMed]

134. Itahana, K.; Itahana, Y.; Dimri, G.P. Colorimetric detection of senescence-associated $\beta$ galactosidase. Methods Mol. Biol. 2013, 965, 143-156. 
135. Han, J.H.; Roh, M.S.; Park, C.-H.; Park, K.C.; Cho, K.H.; Kim, K.H.; Eun, H.C.; Chung, J.H. Selective COX-2 inhibitor, NS-398, inhibits the replicative senescence of cultured dermal fibroblasts. Mech. Ageing Dev. 2004, 125, 359-366. [CrossRef]

136. Goorochurn, R.; Viennet, C.; Granger, C.; Fanian, F.; Varin-Blank, N.; Roy, C.L.; Humbert, P. Biological processes in solar lentigo: Insights brought by experimental models. Exp. Dermatol. 2016, 25, 174-177. [CrossRef]

137. Lee, B.W.; Schwartz, R.A.; Janniger, C.K. Melasma. G. Ital. Dermatol. E Venereol. Organo Uff. Soc. Ital. Dermatol. E Sifilogr. 2017, 152, 36-45.

138. Schalka, S. New data on hyperpigmentation disorders. J. Eur. Acad. Dermatol. Venereol. 2017, 31, 18-21. [CrossRef]

139. Cichorek, M.; Wachulska, M.; Stasiewicz, A.; Tymińska, A. Skin melanocytes: Biology and development. Postepy Dermatol. Alergol. 2013, 30, 30-41. [CrossRef]

140. Imokawa, G.; Miyagishi, M.; Yada, Y. Endothelin-1 as a new melanogen: Coordinated expression of its gene and the tyrosinase gene in UVB-exposed human epidermis. J. Investig. Dermatol. 1995, 105, 32-37. [CrossRef]

141. Starner, R.J.; McClelland, L.; Abdel-Malek, Z.; Fricke, A.; Scott, G. PGE2 is a UVR-inducible autocrine factor for human melanocytes that stimulates tyrosinase activation. Exp. Dermatol. 2010, 19, 682-684. [CrossRef] [PubMed]

142. Pernet, I.; Mayoux, C.; Trompezinski, S.; Schmitt, D.; Viac, J. Modulation of endothelin-1 in normal human keratinocytes by UVA1/B radiations, prostaglandin $\mathrm{E}_{2}$ and peptidase inhibitors. Exp. Dermatol. 2000, 9, 401-406. [CrossRef] [PubMed]

143. Gledhill, K.; Rhodes, L.E.; Brownrigg, M.; Haylett, A.K.; Masoodi, M.; Thody, A.J.; Nicolaou, A.; Tobin, D.J. Prostaglandin-E2 is produced by adult human epidermal melanocytes in response to UVB in a melanogenesis-independent manner. Pigment Cell Melanoma Res. 2010, 23, 394-403. [CrossRef] [PubMed]

144. Scott, G.; Fricke, A.; Fender, A.; McClelland, L.; Jacobs, S. Prostaglandin $\mathrm{E}_{2}$ regulates melanocyte dendrite formation through activation of PKCzeta. Exp. Cell Res. 2007, 313, 3840-3850. [CrossRef]

145. Ma, H.-J.; Ma, H.-Y.; Yang, Y.; Li, P.-C.; Zi, S.-X.; Jia, C.-Y.; Chen, R. $\alpha$-Melanocyte stimulating hormone (MSH) and prostaglandin E2 (PGE2) drive melanosome transfer by promoting filopodia delivery and shedding spheroid granules: Evidences from atomic force microscopy observation. J. Dermatol. Sci. 2014, 76, 222-230. [CrossRef]

146. Scott, G.; Leopardi, S.; Printup, S.; Malhi, N.; Seiberg, M.; Lapoint, R. Proteinase-activated receptor-2 stimulates prostaglandin production in keratinocytes: Analysis of prostaglandin receptors on human melanocytes and effects of PGE2 and PGF2alpha on melanocyte dendricity. J. Investig. Dermatol. 2004, 122, 1214-1224. [CrossRef] [PubMed]

147. Le Clair, M.Z.; Cockburn, M.G. Tanning bed use and melanoma: Establishing risk and improving prevention interventions. Prev. Med. Rep. 2016, 3, 139-144. [CrossRef] [PubMed]

148. Dannenberg, A.J.; Subbaramaiah, K. Targeting cyclooxygenase-2 in human neoplasia: Rationale and promise. Cancer Cell 2003, 4, 431-436. [CrossRef]

149. Hashemi Goradel, N.; Najafi, M.; Salehi, E.; Farhood, B.; Mortezaee, K. Cyclooxygenase-2 in cancer: A review. J. Cell. Physiol. 2018. [CrossRef] [PubMed]

150. Greenhough, A.; Smartt, H.J.M.; Moore, A.E.; Roberts, H.R.; Williams, A.C.; Paraskeva, C.; Kaidi, A. The COX-2/PGE2 pathway: Key roles in the hallmarks of cancer and adaptation to the tumour microenvironment. Carcinogenesis 2009, 30, 377-386. [CrossRef]

151. Kochel, T.J.; Goloubeva, O.G.; Fulton, A.M. Upregulation of Cyclooxygenase-2/Prostaglandin E2 (COX-2/PGE2) Pathway Member Multiple Drug Resistance-Associated Protein 4 (MRP4) and Downregulation of Prostaglandin Transporter (PGT) and 15-Prostaglandin Dehydrogenase (15-PGDH) in Triple-Negative Breast Cancer. Breast Cancer Basic Clin. Res. 2016, 10, 61-70.

152. Müller-Decker, K. Cyclooxygenase-dependent signaling is causally linked to non-melanoma skin carcinogenesis: Pharmacological, genetic, and clinical evidence. Cancer Metastasis Rev. 2011, 30, 343-361. [CrossRef] [PubMed]

153. Reader, J.; Holt, D.; Fulton, A. Prostaglandin E2 EP receptors as therapeutic targets in breast cancer. Cancer Metastasis Rev. 2011, 30, 449-463. [CrossRef] [PubMed]

154. Nakanishi, M.; Rosenberg, D.W. Multifaceted roles of PGE2 in inflammation and cancer. Semin. Immunopathol. 2013, 35, 123-137. [CrossRef] [PubMed] 
155. Yang, Y.; Tang, L.-Q.; Wei, W. Prostanoids receptors signaling in different diseases/cancers progression. J. Recept. Signal Transduct. Res. 2013, 33, 14-27. [CrossRef] [PubMed]

156. Kanekura, T.; Higashi, Y.; Kanzaki, T. Inhibitory effects of 9-cis-retinoic acid and pyrrolidinedithiocarbamate on cyclooxygenase (COX)-2 expression and cell growth in human skin squamous carcinoma cells. Cancer Lett. 2000, 161, 177-183. [CrossRef]

157. An, K.P.; Athar, M.; Tang, X.; Katiyar, S.K.; Russo, J.; Beech, J.; Aszterbaum, M.; Kopelovich, L.; Epstein, E.H.; Mukhtar, H.; et al. Cyclooxygenase-2 expression in murine and human nonmelanoma skin cancers: Implications for therapeutic approaches. Photochem. Photobiol. 2002, 76, 73-80. [CrossRef]

158. Fischer, S.M. Is cyclooxygenase-2 important in skin carcinogenesis? J. Environ. Pathol. Toxicol. Oncol. 2002, 21, 183-191. [CrossRef]

159. Zhan, H.; Zheng, H. The role of topical cyclo-oxygenase-2 inhibitors in skin cancer: Treatment and prevention. Am. J. Clin. Dermatol. 2007, 8, 195-200. [CrossRef]

160. Elmets, C.A.; Ledet, J.J.; Athar, M. Cyclooxygenases: Mediators of UV-Induced Skin Cancer and Potential Targets for Prevention. J. Investig. Dermatol. 2014, 134, 2497-2502. [CrossRef]

161. Fischer, S.M.; Lo, H.H.; Gordon, G.B.; Seibert, K.; Kelloff, G.; Lubet, R.A.; Conti, C.J. Chemopreventive activity of celecoxib, a specific cyclooxygenase-2 inhibitor, and indomethacin against ultraviolet light-induced skin carcinogenesis. Mol. Carcinog. 1999, 25, 231-240. [CrossRef]

162. Burns, E.M.; Tober, K.L.; Riggenbach, J.A.; Schick, J.S.; Lamping, K.N.; Kusewitt, D.F.; Young, G.S.; Oberyszyn, T.M. Preventative topical diclofenac treatment differentially decreases tumor burden in male and female Skh-1 mice in a model of UVB-induced cutaneous squamous cell carcinoma. Carcinogenesis 2013, 34, 370-377. [CrossRef] [PubMed]

163. Wilgus, T.A.; Koki, A.T.; Zweifel, B.S.; Kusewitt, D.F.; Rubal, P.A.; Oberyszyn, T.M. Inhibition of cutaneous ultraviolet light B-mediated inflammation and tumor formation with topical celecoxib treatment. Mol. Carcinog. 2003, 38, 49-58. [CrossRef] [PubMed]

164. Wilgus, T.A.; Koki, A.T.; Zweifel, B.S.; Rubal, P.A.; Oberyszyn, T.M. Chemotherapeutic efficacy of topical celecoxib in a murine model of ultraviolet light B-induced skin cancer. Mol. Carcinog. 2003, 38, 33-39. [CrossRef] [PubMed]

165. Rundhaug, J.E.; Fischer, S.M. Cyclo-oxygenase-2 Plays a Critical Role in UV-induced Skin Carcinogenesis. Photochem. Photobiol. 2008, 84, 322-329. [CrossRef] [PubMed]

166. Müller-Decker, K.; Fürstenberger, G. The cyclooxygenase-2-mediated prostaglandin signaling is causally related to epithelial carcinogenesis. Mol. Carcinog. 2007, 46, 705-710. [CrossRef] [PubMed]

167. Tiano, H.F.; Loftin, C.D.; Akunda, J.; Lee, C.A.; Spalding, J.; Sessoms, A.; Dunson, D.B.; Rogan, E.G.; Morham, S.G.; Smart, R.C.; et al. Deficiency of either cyclooxygenase (COX)-1 or COX-2 alters epidermal differentiation and reduces mouse skin tumorigenesis. Cancer Res. 2002, 62, 3395-3401. [PubMed]

168. Buckman, S.Y.; Gresham, A.; Hale, P.; Hruza, G.; Anast, J.; Masferrer, J.; Pentland, A.P. COX-2 expression is induced by UVB exposure in human skin: Implications for the development of skin cancer. Carcinogenesis 1998, 19, 723-729. [CrossRef] [PubMed]

169. Becker, M.R.; Siegelin, M.D.; Rompel, R.; Enk, A.H.; Gaiser, T. COX-2 expression in malignant melanoma: A novel prognostic marker? Melanoma Res. 2009, 19, 8-16. [CrossRef]

170. Zhou, P.; Qin, J.; Li, Y.; Li, G.; Wang, Y.; Zhang, N.; Chen, P.; Li, C. Combination therapy of PKCᄃ and COX-2 inhibitors synergistically suppress melanoma metastasis. J. Exp. Clin. Cancer Res. 2017, 36, 115. [CrossRef] [PubMed]

171. Tang, J.Y.; Aszterbaum, M.; Athar, M.; Barsanti, F.; Cappola, C.; Estevez, N.; Hebert, J.; Hwang, J.; Khaimskiy, Y.; Kim, A.; et al. Basal Cell Carcinoma Chemoprevention with Nonsteroidal Anti-inflammatory Drugs in Genetically Predisposed PTCH1+/- Humans and Mice. Cancer Prev. Res. (Phila. Pa.) 2010, 3, $25-34$. [CrossRef] [PubMed]

172. Wilgus, T.A.; Ross, M.S.; Parrett, M.L.; Oberyszyn, T.M. Topical application of a selective cyclooxygenase inhibitor suppresses UVB mediated cutaneous inflammation. Prostaglandins Other Lipid Mediat. 2000, 62, 367-384. [CrossRef]

173. Hatamipour, M.; Johnston, T.P.; Sahebkar, A. One Molecule, Many Targets and Numerous Effects: The Pleiotropy of Curcumin Lies in its Chemical Structure. Curr. Pharm. Des. 2018, 24, 2129-2136. [CrossRef] [PubMed] 
174. Zhou, H.; Beevers, C.S.; Huang, S. The targets of curcumin. Curr. Drug Targets 2011, 12, 332-347. [CrossRef] [PubMed]

175. Liu, X.; Zhang, R.; Shi, H.; Li, X.; Li, Y.; Taha, A.; Xu, C. Protective effect of curcumin against ultraviolet A irradiation-induced photoaging in human dermal fibroblasts. Mol. Med. Rep. 2018, 17, 7227-7237. [CrossRef] [PubMed]

176. Shen, L.-R.; Parnell, L.D.; Ordovas, J.M.; Lai, C.-Q. Curcumin and aging. BioFactors 2013, 39, $133-140$. [CrossRef] [PubMed]

177. Jobin, C.; Bradham, C.A.; Russo, M.P.; Juma, B.; Narula, A.S.; Brenner, D.A.; Sartor, R.B. Curcumin blocks cytokine-mediated NF-kappa B activation and proinflammatory gene expression by inhibiting inhibitory factor I-kappa B kinase activity. J. Immunol. 1999, 163, 3474-3483.

178. Shishodia, S. Molecular mechanisms of curcumin action: Gene expression. BioFactors 2013, 39, 37-55. [CrossRef]

179. Kunnumakkara, A.B.; Bordoloi, D.; Harsha, C.; Banik, K.; Gupta, S.C.; Aggarwal, B.B. Curcumin mediates anticancer effects by modulating multiple cell signaling pathways. Clin. Sci. 2017, 131, 1781-1799. [CrossRef]

180. Wang, J.; Ma, J.; Gu, J.-H.; Wang, F.-Y.; Shang, X.-S.; Tao, H.-R.; Wang, X. Regulation of type II collagen, matrix metalloproteinase-13 and cell proliferation by interleukin-1 $\beta$ is mediated by curcumin via inhibition of NF-кB signaling in rat chondrocytes. Mol. Med. Rep. 2017, 16, 1837-1845. [CrossRef]

181. Hu, H.L.; Forsey, R.J.; Blades, T.J.; Barratt, M.E.; Parmar, P.; Powell, J.R. Antioxidants may contribute in the fight against ageing: An in vitro model. Mech. Ageing Dev. 2000, 121, 217-230. [CrossRef]

182. Palmer, D.M.; Kitchin, J.S. Oxidative damage, skin aging, antioxidants and a novel antioxidant rating system. J. Drugs Dermatol. 2010, 9, 11-15. [PubMed]

183. Pandel, R.; Poljšak, B.; Godic, A.; Dahmane, R. Skin photoaging and the role of antioxidants in its prevention. ISRN Dermatol. 2013, 2013, 930164. [CrossRef] [PubMed]

184. Cho, J.-W.; Park, K.; Kweon, G.R.; Jang, B.-C.; Baek, W.-K.; Suh, M.-H.; Kim, C.-W.; Lee, K.-S.; Suh, S.-I. Curcumin inhibits the expression of COX-2 in UVB-irradiated human keratinocytes (HaCaT) by inhibiting activation of AP-1: p38 MAP kinase and JNK as potential upstream targets. Exp. Mol. Med. 2005, 37, 186-192. [CrossRef] [PubMed]

185. Lee, K.M.; Lee, K.W.; Jung, S.K.; Lee, E.J.; Heo, Y.-S.; Bode, A.M.; Lubet, R.A.; Lee, H.J.; Dong, Z. Kaempferol inhibits UVB-induced COX-2 expression by suppressing Src kinase activity. Biochem. Pharmacol. 2010, 80, 2042-2049. [CrossRef] [PubMed]

186. Tong, X.; Van Dross, R.T.; Abu-Yousif, A.; Morrison, A.R.; Pelling, J.C. Apigenin Prevents UVB-Induced Cyclooxygenase 2 Expression: Coupled mRNA Stabilization and Translational Inhibition. Mol. Cell. Biol. 2007, 27, 283-296. [CrossRef] [PubMed]

187. Sung, M.-S.; Lee, E.-G.; Jeon, H.-S.; Chae, H.-J.; Park, S.J.; Lee, Y.C.; Yoo, W.-H. Quercetin Inhibits IL-1 $\beta$-Induced Proliferation and Production of MMPs, COX-2, and PGE2 by Rheumatoid Synovial Fibroblast. Inflammation 2012, 35, 1585-1594. [CrossRef]

188. Farrar, M.D.; Nicolaou, A.; Clarke, K.A.; Mason, S.; Massey, K.A.; Dew, T.P.; Watson, R.E.; Williamson, G.; Rhodes, L.E. A randomized controlled trial of green tea catechins in protection against ultraviolet radiation-induced cutaneous inflammation. Am. J. Clin. Nutr. 2015, 102, 608-615. [CrossRef]

189. Yarla, N.S.; Bishayee, A.; Sethi, G.; Reddanna, P.; Kalle, A.M.; Dhananjaya, B.L.; Dowluru, K.S.V.G.K.; Chintala, R.; Duddukuri, G.R. Targeting arachidonic acid pathway by natural products for cancer prevention and therapy. Semin. Cancer Biol. 2016, 40-41, 48-81. [CrossRef]

190. Nam, N.-H. Naturally occurring NF-kappaB inhibitors. Mini Rev. Med. Chem. 2006, 6, 945-951. [CrossRef]

191. Tanaka, K.; Asamitsu, K.; Uranishi, H.; Iddamalgoda, A.; Ito, K.; Kojima, H.; Okamoto, T. Protecting skin photoaging by NF-kappaB inhibitor. Curr. Drug Metab. 2010, 11, 431-435. [CrossRef] [PubMed]

192. Hwang, D.; Fischer, N.H.; Jang, B.C.; Tak, H.; Kim, J.K.; Lee, W. Inhibition of the expression of inducible cyclooxygenase and proinflammatory cytokines by sesquiterpene lactones in macrophages correlates with the inhibition of MAP kinases. Biochem. Biophys. Res. Commun. 1996, 226, 810-818. [CrossRef] [PubMed]

193. Won, Y.-K. Chemopreventive activity of parthenolide against UVB-induced skin cancer and its mechanisms. Carcinogenesis 2004, 25, 1449-1458. [CrossRef] 
194. Tsai, M.-H.; Hsu, L.-F.; Lee, C.-W.; Chiang, Y.-C.; Lee, M.-H.; How, J.-M.; Wu, C.-M.; Huang, C.-L.; Lee, I.-T. Resveratrol inhibits urban particulate matter-induced COX-2/PGE2 release in human fibroblast-like synoviocytes via the inhibition of activation of NADPH oxidase/ROS/NF-kB. Int. J. Biochem. Cell Biol. 2017, 88, 113-123. [CrossRef]

195. Kowalczyk, M.C.; Junco, J.J.; Kowalczyk, P.; Tolstykh, O.; Hanausek, M.; Slaga, T.J.; Walaszek, Z. Effects of combined phytochemicals on skin tumorigenesis in SENCAR mice. Int. J. Oncol. 2013, 43, 911-918. [CrossRef] [PubMed]

196. Kundu, J.K.; Shin, Y.K.; Kim, S.H.; Surh, Y.-J. Resveratrol inhibits phorbol ester-induced expression of COX-2 and activation of NF-kappaB in mouse skin by blocking IkappaB kinase activity. Carcinogenesis 2006, 27, 1465-1474. [CrossRef] [PubMed]

197. Subedi, L.; Lee, T.H.; Wahedi, H.M.; Baek, S.-H.; Kim, S.Y. Resveratrol-Enriched Rice Attenuates UVB-ROS-Induced Skin Aging via Downregulation of Inflammatory Cascades. Oxid. Med. Cell. Longev. 2017, 2017, 8379539. [CrossRef]

198. Ren, Z.; Wang, L.; Cui, J.; Huoc, Z.; Xue, J.; Cui, H.; Mao, Q.; Yang, R. Resveratrol inhibits NF-kB signaling through suppression of $\mathrm{p} 65$ and IkappaB kinase activities. Pharmazie 2013, 68, 689-694.

199. Tsai, M.-L.; Lai, C.-S.; Chang, Y.-H.; Chen, W.-J.; Ho, C.-T.; Pan, M.-H. Pterostilbene, a natural analogue of resveratrol, potently inhibits 7,12-dimethylbenz[a]anthracene (DMBA)/12-O-tetradecanoylphorbol13-acetate (TPA)-induced mouse skin carcinogenesis. Food Funct. 2012, 3, 1185-1194. [CrossRef]

200. Cichocki, M.; Paluszczak, J.; Szaefer, H.; Piechowiak, A.; Rimando, A.M.; Baer-Dubowska, W. Pterostilbene is equally potent as resveratrol in inhibiting 12-O-tetradecanoylphorbol-13-acetate activated NFkappaB, AP-1, COX-2, and iNOS in mouse epidermis. Mol. Nutr. Food Res. 2008, 52 (Suppl. 1), S62-S70.

201. Katiyar, S.K.; Afaq, F.; Perez, A.; Mukhtar, H. Green tea polyphenol (-)-epigallocatechin-3-gallate treatment of human skin inhibits ultraviolet radiation-induced oxidative stress. Carcinogenesis 2001, 22, 287-294. [CrossRef] [PubMed]

202. Seok, J.K.; Lee, J.; Kim, Y.M.; Boo, Y.C. Punicalagin and (-)-Epigallocatechin-3-Gallate Rescue Cell Viability and Attenuate Inflammatory Responses of Human Epidermal Keratinocytes Exposed to Airborne Particulate Matter PM10. Skin Pharmacol. Physiol. 2018, 31, 134-143. [CrossRef] [PubMed]

203. Soriani, M.; Rice-Evans, C.; Tyrrell, R.M. Modulation of the UVA activation of haem oxygenase, collagenase and cyclooxygenase gene expression by epigallocatechin in human skin cells. FEBS Lett. 1998, 439, $253-257$. [CrossRef]

204. Lee, J.H.; Chung, J.H.; Cho, K.H. The effects of epigallocatechin-3-gallate on extracellular matrix metabolism. J. Dermatol. Sci. 2005, 40, 195-204. [CrossRef] [PubMed]

205. Dooley, A.; Shi-Wen, X.; Aden, N.; Tranah, T.; Desai, N.; Denton, C.P.; Abraham, D.J.; Bruckdorfer, R. Modulation of collagen type I, fibronectin and dermal fibroblast function and activity, in systemic sclerosis by the antioxidant epigallocatechin-3-gallate. Rheumatology 2010, 49, 2024-2036. [CrossRef] [PubMed]

206. Park, M.-Y.; Kwon, H.-J.; Sung, M.-K. Evaluation of aloin and aloe-emodin as anti-inflammatory agents in aloe by using murine macrophages. Biosci. Biotechnol. Biochem. 2009, 73, 828-832. [CrossRef] [PubMed]

207. Misawa, E.; Tanaka, M.; Saito, M.; Nabeshima, K.; Yao, R.; Yamauchi, K.; Abe, F.; Yamamoto, Y.; Furukawa, F. Protective effects of Aloe sterols against UVB-induced photoaging in hairless mice. Photodermatol. Photoimmunol. Photomed. 2017, 33, 101-111. [CrossRef] [PubMed]

208. Kiraly, A.J.; Soliman, E.; Jenkins, A.; Van Dross, R.T. Apigenin inhibits COX-2, PGE2, and EP1 and also initiates terminal differentiation in the epidermis of tumor bearing mice. Prostaglandins Leukot. Essent. Fat. Acids 2016, 104, 44-53. [CrossRef]

209. Furuhashi, I.; Iwata, S.; Sato, T.; Inoue, H.; Shibata, S. Inhibition by licochalcone A, a novel flavonoid isolated from liquorice root, of IL-1 $\beta$-induced PGE2 production in human skin fibroblasts. J. Pharm. Pharmacol. 2005, 57, 1661-1666. [CrossRef]

210. Wu, D.; Yuan, P.; Ke, C.; Xiong, H.; Chen, J.; Guo, J.; Lu, M.; Ding, Y.; Fan, X.; Duan, Q.; et al. Salidroside suppresses solar ultraviolet-induced skin inflammation by targeting cyclooxygenase-2. Oncotarget 2016, 7, 25971-25982. [CrossRef]

211. Tsai, M.-H.; Lin, Z.-C.; Liang, C.-J.; Yen, F.-L.; Chiang, Y.-C.; Lee, C.-W. Eupafolin inhibits PGE2 production and COX2 expression in LPS-stimulated human dermal fibroblasts by blocking JNK/AP-1 and Nox2/p47phox pathway. Toxicol. Appl. Pharmacol. 2014, 279, 240-251. [CrossRef] 
212. Fuller, B.; Smith, D.; Howerton, A.; Kern, D. Anti-inflammatory effects of CoQ10 and colorless carotenoids. J. Cosmet. Dermatol. 2006, 5, 30-38. [CrossRef] [PubMed]

213. Kwon, J.Y.; Lee, K.W.; Kim, J.-E.; Jung, S.K.; Kang, N.J.; Hwang, M.K.; Heo, Y.-S.; Bode, A.M.; Dong, Z.; Lee, H.J. Delphinidin suppresses ultraviolet B-induced cyclooxygenases-2 expression through inhibition of MAPKK4 and PI-3 kinase. Carcinogenesis 2009, 30, 1932-1940. [CrossRef] [PubMed]

214. Yoshizaki, N.; Fujii, T.; Masaki, H.; Okubo, T.; Shimada, K.; Hashizume, R. Orange peel extract, containing high levels of polymethoxyflavonoid, suppressed UVB-induced COX-2 expression and PGE2 production in HaCaT cells through PPAR- $\gamma$ activation. Exp. Dermatol. 2014, 23, 18-22. [CrossRef]

215. Das, U.; Manna, K.; Sinha, M.; Datta, S.; Das, D.K.; Chakraborty, A.; Ghosh, M.; Saha, K.D.; Dey, S. Role of ferulic acid in the amelioration of ionizing radiation induced inflammation: A murine model. PLoS ONE 2014, 9, e97599. [CrossRef] [PubMed]

216. Kim, J.-E.; Son, J.E.; Jang, Y.J.; Lee, D.E.; Kang, N.J.; Jung, S.K.; Heo, Y.-S.; Lee, K.W.; Lee, H.J. Luteolin, a novel natural inhibitor of tumor progression locus 2 serine/threonine kinase, inhibits tumor necrosis factor-alpha-induced cyclooxygenase-2 expression in JB6 mouse epidermis cells. J. Pharmacol. Exp. Ther. 2011, 338, 1013-1022. [CrossRef]

217. Novitskiy, G.; Potter, J.J.; Rennie-Tankersley, L.; Mezey, E. Identification of a Novel NF-kB-binding Site with Regulation of the Murine $\alpha_{2}$ (I) Collagen Promoter. J. Biol. Chem. 2004, 279, 15639-15644. [CrossRef] [PubMed]

218. Kaur, S.; Kizoulis, M.; Fantasia, J.; Oddos, T.; Bigot, N.; Galera, P.; Tucker-Samaras, S.; Leyden, J.J.; Southall, M.D. 4-Hexyl-1,3-phenylenediol, a nuclear factor- $\mathrm{B}$ inhibitor, improves photodamaged skin and clinical signs of ageing in a double-blinded, randomized controlled trial. Br. J. Dermatol. 2015, 173, 218-226. [CrossRef]

219. Long, X.; Zeng, X.; Zhang, F.; Wang, X. Influence of quercetin and x-ray on collagen synthesis of cultured human keloid-derived fibroblasts. Chin. Med. Sci. J. 2006, 21, 179-183.

220. Bos, J.D.; Meinardi, M.M. The 500 Dalton rule for the skin penetration of chemical compounds and drugs. Exp. Dermatol. 2000, 9, 165-169. [CrossRef]

221. Korinth, G.; Wellner, T.; Schaller, K.H.; Drexler, H. Potential of the octanol-water partition coefficient $(\log \mathrm{P})$ to predict the dermal penetration behaviour of amphiphilic compounds in aqueous solutions. Toxicol. Lett. 2012, 215, 49-53. [CrossRef]

222. Potts, R.O.; Guy, R.H. Predicting skin permeability. Pharm. Res. 1992, 9, 663-669. [CrossRef]

223. Jäger, R.; Lowery, R.P.; Calvanese, A.V.; Joy, J.M.; Purpura, M.; Wilson, J.M. Comparative absorption of curcumin formulations. Nutr. J. 2014, 13, 11. [CrossRef] [PubMed]

224. Ng, S.-F.; Rouse, J.J.; Sanderson, F.D.; Meidan, V.; Eccleston, G.M. Validation of a static Franz diffusion cell system for in vitro permeation studies. AAPS PharmSciTech 2010, 11, 1432-1441. [CrossRef] [PubMed]

225. Bartosova, L.; Bajgar, J. Transdermal drug delivery in vitro using diffusion cells. Curr. Med. Chem. 2012, 19, 4671-4677. [CrossRef] [PubMed]

(C) 2019 by the author. Licensee MDPI, Basel, Switzerland. This article is an open access article distributed under the terms and conditions of the Creative Commons Attribution (CC BY) license (http:/ / creativecommons.org/licenses/by/4.0/). 